\title{
Omics Methodologies: New Tools in Aquaculture Studies
}

\author{
María-José Prieto-Álamo, Inmaculada Osuna-Jiménez, \\ Nieves Abril, José Alhama, Carmen Pueyo and Juan López-Barea \\ Department of Biochemistry and Molecular Biology, University of Córdoba \\ Agrifood Campus of International Excellence, ceiA3
}

Spain

\section{Introduction}

According to the FAO, a growing percentage of world aquatic production is derived from aquaculture, whose importance is increasing dramatically due to commercial overfishing and a growing demand for seafood (FAO, 2010). In 1980, aquaculture production represented $9 \%$ of fishery resources; by 2010 , it had increased to $43 \%$. It is thought that such a production will need to double in the next 25 years. The FAO is promoting aquaculture because it is an important source of income and employment and also because of its great contribution to food security and the development of many countries. Currently, there are three main challenges for developing productive, feasible and sustainable aquaculture: 1) diversification of the proteins used for the feeds, 2) resolution of problems derived from stressful conditions, diseases and/or deterioration of environmental conditions, and 3) introduction of new species to make this industry less vulnerable to market demand (COM, 2002). The Senegalese sole (Solea senegalensis) is a flatfish species with a high potential for use in marine aquaculture diversification. The cultivation of sole has been successful under several husbandry conditions, but the frequent occurrence of opportunistic diseases and its high sensitivity to different stressors, such as manipulation, pollutants, etc., make sole unable to be produced industrially (Cañavate, 2005; Dinis et al., 1999). Consequently, the identification of biomarkers responsive to pathological situations and pollutants will help to prevent health problems and to improve their farming.

Biomarkers provide evidence of alterations by physiological or environmental conditions (López-Barea, 1995a). The so-called "classic" biomarkers are suggested a priori by virtue of their biological roles but are rather biased because they concentrate on a small number of proteins, excluding others that are also altered in the same conditions but whose relationship with the physiological or environmental changes is unknown (López-Barea \& Gómez-Ariza, 2006). In 1989, a group at the University of Cordoba (UCO) began to develop a battery of biomarkers sensitive to physiological or environmental changes in several bioindicator species, including bivalves, crustaceans, fish, mammals and mammalian cell lines. A variety of biochemical parameters were included, such as phase I (ethoxyresorufinO-deethylase, EROD) or phase II biotransforming enzymes (GSH transferase, GST), antioxidative defences (superoxide dismutases, SOD; catalase, CAT; glutathione 
peroxidases, GSHPx, glucose-6P and 6P-gluconate dehydrogenases, glutathione reductase, GSSGrase), neurotransmission-linked esterase activities, such as acetylcholine (AcChE) and carboxyl esterases $(\mathrm{CbE})$, oxidative damages to biomolecules, including DNA (8-oxo-dG), proteins (protein-SSG mixed disulphides), lipids (malondialdehyde, MDA), and the glutathione content and redox status (total glutathione, GSSG/GSH). The UCO group also developed new biochemical indicators that are altered by physiological or environmental changes, such as the levels of individual GST and SOD isoenzymes, the activation of promutagens to genotoxins by exposure to extracts of reference or exposed animals -a global measure of biotransforming capacity- and the metallothionein (MT) levels using a new and extremely sensitive HPLC-based fluorescent assay.

The utility of these "classic" biochemical biomarkers was later validated by the UCO group in studies carried out preferentially in natural sites in Spain, Slovakia and Tunisia, and contrasted with experimental exposures to model contaminants carried out under controlled conditions. These studies were reported in the following publications, limited in this review to those made in fish, and listed here by their date of publication: Rodriguez-Ariza et al. (1992, 1993, 1994a, 1994b), Martínez-Lara et al. (1992, 1996, 1997), Pedrajas et al. (1993, 1995, 1998), López-Barea (1995b), Lenartova et al. (1997), López-Barea \& Pueyo (1998), Cousinou et al. $(1999,2000)$, Alhama et al. $(2006,2010)$, Romero-Ruiz et al. $(2003,2008)$, and Jebali et al. (2008). These "classic" biochemical biomarkers also responded to physiological changes, including oxidative alterations promoted by different feeding schemes, as described in Pascual et al. (1995a, 1995b, 1997, 2003) and Cánovas-Conesa et al. (2007).

While genes typically exert their functions at the protein level, genetic responses to stress are often regulated at the transcriptional level. Therefore, the determination of transcriptional profiles has become an essential approach in understanding the coordinated gene response to various physiological and pathological variables. The construction of cDNA libraries by suppression subtractive hybridization (SSH) (Prieto-Álamo et al., 2009; Williams et al., 2003) is a fundamental methodology used in differential expression studies with non-model species because it enables the identification of genes with no previous knowledge of their sequences. SSH is a PCR-based technique for generating cDNAs enriched in differentially expressed genes, useful for large-scale gene identification in non-model organisms (Diatchenko et al., 1996). Unlike SSH, which only provides qualitative results, DNA microarrays give semiquantitative (fold-variation) data, and more importantly, permit, in a single experiment, the analysis of the levels of thousands of transcripts, making them a valuable high-throughput methodology in Functional Genomics. Moreover, heterologous hybridization allows the use of microarrays made from transcripts of one species to probe gene expression in other related species. Real-time $q R T-P C R$ has become a reference method to detect and quantify transcripts and to validate the results obtained with other techniques such as subtractive libraries or microarrays.

The UCO team gained wide experience in quantifying changes occurring at the mRNA level by RT-PCR. Of relevance is the devise of new approaches for the quantification of the exact number of transcript molecules and their application to a wide variety of organisms and conditions. This team developed, validated and optimised relative quantifications using complex multiplexed RT-PCR (Gallardo-Madueño et al., 1998; Manchado et al., 2000; Michan et al., 1999; Monje-Casas et al., 2001; Prieto-Álamo et al., 2000; Pueyo et al., 2002) and absolute quantification by real-time RT-PCR (Jiménez et al., 
2005; Jurado et al., 2003, 2007; Montes-Nieto et al., 2007; Prieto-Álamo et al., 2003, 2009). They also developed a quantitatively rigorous approach based on a combination of multiplexed and real-time RT-PCR to increase the number of transcripts to be quantified simultaneously without compromising the sensitivity, reliability and repetitiveness of the absolute measurements (Jurado et al., 2003; Michan et al., 2005; Monje-Casas et al., 2004; Ruiz-Laguna et al., 2005, 2006). These studies have demonstrated the potential benefits of absolute transcript quantifications in studies of tissue-specific expression profiles (Jurado et al., 2003, 2007; Prieto-Álamo et al., 2003, 2009; Ruiz-Laguna et al., 2005), of changes associated with growth stages or with the age or sex of an individual and have been particularly useful in studies with free-living animals (Jiménez et al., 2005; Michan et al., 2005; Monje-Casas et al., 2004; Prieto-Álamo et al., 2003; Ruiz-Laguna et al., 2005, 2006). We have demonstrated that the main drawback of relative quantifications is the variability of most popular internal standards. By comparing the differences in the transcript molecules with the conventional fold variations, we have also shown that relative quantifications grossly overestimate changes affecting poorly transcribed genes in comparison with highly abundant mRNAs.

Proteomics addresses the post-genomic challenge of examining the entire complement of proteins (proteome) expressed by a genome in a cell, tissue or organ at a given time under defined conditions (James, 1997). Protein expression is modulated at different levels from transcription to the maturation of the polypeptides produced by the translation of mature mRNAs. Proteins were initially separated by two-dimensional electrophoresis (2-DE; Wilkins et al., 1996), and their expression was analysed by 2D software (Melanie, etc.). Proteins were identified by mass spectrometry analysis of their peptide mass fingerprint (MALDI-TOFPMF) or de novo sequencing of some peptides (nESI-MS/MS), comparing the results with public databases (Simpson, 2003). 2-DE, which is labour-intensive and has low reproducibility, requires a large amount of sample, and its narrow dynamic range is problematic with proteins of extreme $\mathrm{Mr} / \mathrm{pI}$. Shotgun proteomic methods allow the analysis of complex protein mixtures after full digestion by multidimensional separation coupling tandem liquid chromatography (LC/LC) and MS/MS (Washburn et al., 2001). The application of proteomic technology faces the problem of the lack of genomic information on most non-model sentinel organisms. This makes it difficult to identify differentially expressed proteins by high-throughput methods such as MALDI-TOF-PMF (López-Barea \& Gómez-Ariza, 2006).

\section{Conventional aquaculture studies with Solea senegalensis}

\subsection{Early studies}

Studies of sole aquaculture began in Faro (S Portugal) and Cádiz (SW Spain) to produce good quality larvae and juveniles (Dinis et al., 1999). Broodstock spawning studies established optimal feeding regimes by combining squid (Loligo vulgaris) and polychaetes (Hediste diversicolor) at the final maturation stages. Spawning was studied in terms of temperature (stopped $<16{ }^{\circ} \mathrm{C}$ ), duration (4-6 months), egg fertilisation rate $(20-100 \%)$ and viable egg rate (72\%). Larvae hatch at $2.4 \mathrm{~mm}$ and accept Artemia nauplii as the first prey two days after hatching (DAH). Metamorphosis spans from 11 to $19 \mathrm{DAH}$, at which point the fish are fed live Artemia metanauplii. They reach $16 \mathrm{~mm}$ at $40 \mathrm{DAH}$ and $35 \mathrm{~cm} / 450 \mathrm{~g}$ after 1 year, with $8 \%$ survival. Pasteurellosis can cause pigmentation abnormalities and 
malformations associated with eye migration and can progress to death (Dinis et al., 1999).

The potential of sole for aquaculture was reviewed some time later (Cañavate, 2005). Although important progress in reproduction techniques was reached, much basic knowledge remained lacking. Ongrowth was successfully carried out, but progress was limited by opportunistic diseases due to suboptimal rearing conditions resulting in an inability of the sole to achieve an adequate physiological status for resistance. Growth, survival and pigmentation were studied during sole growth in tanks with three bottom types (Rodiles et al., 2005). The final length and weight was similar in the sand, white and dark conditions, but different pigmentation patterns appeared on the sand (clear, dark) and white bottoms (clear, brown, dark). The homogeneous dark pattern, preferred by markets, is only obtained in tanks with a dark bottom. A lower survival rate was found on sand bottoms due to pathologies derived from the difficulties in maintaining the sand bed.

\subsection{Organ development and reproductive studies}

Digestive tract development was studied in larvae until $30 \mathrm{DAH}$, which involved the assessment of histology, digestive enzymes, lipids, proteins and carbohydrates in the buccopharyngeal cavity, oesophagus, early stomach, anterior and posterior intestine, pancreas and liver (Ribeiro et al., 1999a). The digestive tract elongates in metamorphosis, increasing absorption. Phosphatases, lipase and aminopeptidase have been detected starting at $2 \mathrm{DAH}$ and the levels increase during development. Proteins abound in the intestinal epithelium and exocrine pancreas, and neutral lipids are found at the yolk sac intestinal epithelium and liver. After 31 DAH larvae ingest, digest and absorb nutrients because they now have a complete digestive tract. A time course of pancreatic and intestinal enzymes was studied in larvae until 31 DAH (Ribeiro et al., 1999b). Digestive enzymes increase until 10 $\mathrm{DAH}$ then decrease until $18 \mathrm{DAH}$, a pattern typical of developing animals. Alkaline phosphatase abounds from 21-27 $\mathrm{DAH}$, during the development of brush border membranes, with a parallel decrease in the cytosolic enzyme, Leu-Ala peptidase.

Thyroid development was studied in sole larvae by histo- and immunohistochemistry to synchronise larval development and improve fish production (Ortiz-Delgado et al., 2006). The first follicle is visible by the first feeding; increases during metamorphosis and has adult characteristics by $30 \mathrm{DAH}$. Thyroid hormones decrease to undetectable levels at yolk-sac reabsorption. T3 and T4 are detected by $6 \mathrm{DAH}$ and increase during metamorphosis.

Seasonal profiles of sex steroids $-17 \beta$-estradiol $(17 \beta-\mathrm{E})$, testosterone $(\mathrm{T}), 11-$ ketotestosterone


an attempt to achieve steroid-induced maturation (García-López et al., 2006a). Females have six maturation stages, as follows: early, intermediate and final ovarian development, then partially, mid and spawned out. By summer's end, a new gonadal cycle starts, as demonstrated by increased reproductive parameters. By mid-autumn some females reach advanced maturation stages, which coincide with a peak of running males. By the start of spring, ovarian development reaches its peak, and plasma steroid levels are maximal at the start of the spawning period, which occurs from March to June. In parallel with oocyte and sperm release, the proportion of spawned out fish and non-running males increases, and steroid levels decline. The high levels of $17,20 \beta-P$ during spawning make it a candidate for a maturation-inducing steroid. 
Testicular development was also studied (García-López et al., 2006b). The spermatogenetic cycle consists of the following five stages: early (I), mid (II), and late (III) spermatogenesis, maturation (IV), and recovery (V). In the summer, stage I and V testes are found with low values of sex steroids and $\mathrm{I}_{\mathrm{G}}$ (gonadosomatic index). Recrudescence begins in autumn, with an initial increase of $\mathrm{I}_{\mathrm{G}} 11-\mathrm{KT}$ and $\mathrm{T}$ and the appearance of stage II and III testes. In the winter, 11-KT and $\mathrm{T}$ peak and soon decrease, and $\mathrm{I}_{\mathrm{G}}$ slightly declines. In the spring, 11-KT and $\mathrm{T}$ decline further, while $\mathrm{I}_{\mathrm{G}}$ slightly increases and running males peak with stage IV testes. Sperm production and quality was assessed in wild-captured and F1 broodstock fish (Cabrita et al., 2006). Males produce motile sperm from February to November, with specific peaks of high spermiation and fluent males. Sperm volume and cell density is lower in F1 males than in wild-captured broodstock.

Ovarian development was also studied (García-López et al., 2007). In the autumn/winter, oocytes progress to vitellogenic stages in parallel with high levels of $\mathrm{K}$ (condition factor), $\mathrm{I}_{\mathrm{G}}$, and plasma $17 \beta-\mathrm{E}$ and $\mathrm{T}$. In the late winter/early spring, development is maximal, with females at intermediate and final maturation and $\mathrm{K}, \mathrm{I}_{\mathrm{G}}, 17 \beta-\mathrm{E}$ and $\mathrm{T}$ peaking. Steroid levels are lower in cultured sole than in naturally spawning females, leading to atresia and lack of oocyte maturation, thus reducing ovary size with declining $\mathrm{K}, \mathrm{I}_{\mathrm{G}}$, and $17 \beta$-El and $\mathrm{T}$ levels and many perinucleolar oocytes. The amount of circulating $17,20 \beta-\mathrm{P}$, the putative maturation-inducing steroid, remains near constant through the period, suggesting that oocytes are unresponsive to its stimulation.

Skeletal development and malformations are a bottleneck in sole aquaculture. Maturation and abnormalities of the vertebral column and caudal skeleton have been studied in sole (Gavaia et al., 2002). Different defects are found in the caudal complex and the vertebral column, and $44 \%$ of fish show at least one defect. While the causes are unknown, their high incidence may reflect rearing and/or feeding problems. The tissue distribution and evolution of bone Gla (Bgp) and matrix Gla proteins (Mgp) and $\mathrm{Ca}^{2+}$ deposition were studied in zebrafish during larval development and in adult tissues as well as sole metamorphosis (Gavaia et al., 2006). In zebrafish, Bpg and Mpg accumulate mainly in the matrix of skeletal structures already calcified or under calcification. In sole metamorphosis, Bpg and Mpg increase in parallel to the calcification of the axial skeleton. In both species, Mpg also accumulates in non-mineralised vessel walls.

\subsection{Nutrition studies}

Studies on the requirements, catabolism and assimilation of amino acids (AAs) were carried out in early larval, metamorphic and post-larval sole. Initial studies on indispensable (IAA) and dispensable (DAA) amino acids (Rønnestad et al., 2001), showed that sole assimilated most $(85 \%)$ of the dietary IAAs and catabolised most of the DAAs. Such results were confirmed after studying the bioavailability of several AAs in larvae (Conceição et al., 2003). The demand and availability of AAs and proteins in relation to digestive capacity were reviewed, and AAs sources were described, highlighting the regulatory role of cholecystokinin and peristaltic activity (Rønnestad et al., 2003). A balanced AA profile improved amino acid assimilation in post-larval sole (Aragão et al., 2004a). Changes in AA requirements and dietary imbalances were studied in Sparus aurata and S. senegalensis (Aragão et al., 2004b); the AA profiles of both changed during ontogeny, especially in sole due to its marked metamorphosis. AA imbalances were found during development. In both 
species, Phe/Tyr addition was studied to assess the effects on metamorphosis after their conversion into thyroid hormones (Pinto et al., 2010). While Phe did not affect sole metamorphosis, dietary Tyr increased the production of thyroid hormones, which was beneficial for sole metamorphosis.

The nutritional physiology of sole development was studied to optimise diets and understand limiting factors in weaning (Conceiçao et al., 2007). Larvae have a high capacity to digest live prey, even at the early stages. Use of inert microdiets in co-feeding with Artemia resulted in the development of intestinal activity and enhanced survival, although it was also accompanied by low growth and high size dispersal. Fatty acid absorption increases with their degree of unsaturation, and larvae spare DHE from catabolism. Rotifers and Artemia are deficient in one or more AAs, such as His, Lys, Arg, Thr, or those containing sulphur and aromatic rings, depending on the larval stage; balancing the dietary AA profile with dipeptides increases retention and decreases catabolism in Artemia-fed larvae.

The effects of non-protein energy levels on growth and oxidative status were studied in sole fed diets with 4 energy levels (Rueda-Jasso et al., 2004). Cellular energy allocation showed differences in liver, but not in muscle. TBARS were higher in fish fed a diet with high lipid content, in parallel to high CAT and SOD activity. Yet, the protein source or energy levels had no major impact on sole growth, nutrient utilisation or fatty acid composition (Valente et al., 2011). Quantitative lipid imbalances and a low protein/neutral lipid ratio increased the accumulation of lipid droplets in the enterocytes and lowered fatty acid absorption in larvae (Morais et al., 2005). The effects of a neutral lipid level and source were studied in marine fish larvae (Morais et al., 2007). A growth-depressing effect of high neutral lipids, as assessed by lower digestive enzyme activity, absorption and/or food intake was reported. In larvae, lipid transport from enterocytes to the body is more critical than lipolytic activities. Phospholipid digestion is more efficient than that of neutral lipids, whose excess leads to the accumulation of large lipid droplets in the enterocytes, reducing fatty acid absorption and growth.

The feed transit, protein and energy digestibility of practical feed were assessed in sole (Dias et al., 2010). Protein digestibility is high for fishmeal and corn gluten, intermediate for soybean meal, and moderate for wheat meal. Energy digestibility varies from 88 to $93 \%$ for soybean meal, corn gluten and anchovy fishmeal and is $73 \%$ in wheat meal. Thus, flatfish, despite its high dietary protein requirement, digest vegetable ingredients quite well, suggesting that the development of practical feeds with high levels of plant-protein sources would be beneficial.

\subsection{Conventional biomarker studies in S. senegalensis aquaculture}

Nearly 15 years after the studies of the UCO group, the use of biomarkers to follow fish physiology and pollution effects has become popular and is now applied by most groups. Antioxidant enzymes, stress proteins, lipid peroxides and histology were studied in sole larvae (Fernández-Díaz et al., 2006) fed on the following 3 diets: live Artemia nauplii, microcapsules, and vitamin A-supplemented microcapsules. Live-fed larvae grow larger and undergo faster metamorphosis than microcapsule-fed larvae, although all groups have near $80 \%$ survival. Vitamin A improves the growth and development compared to an inert diet. Artemia-fed larvae have organs with normal development, but histological alterations 
are seen in larvae fed an inert diet. Catalase (CAT), superoxide dismutase (SOD), total GSHperoxidase (t-GPX), lipid peroxides (MDA) and stress proteins (HSP70, not HSP60) are dietand age-dependent. Inert diet-fed larvae have similar biomarker responses, but different $(p<0.05)$ from Artemia-fed larvae. Higher antioxidant defences are attributed to the start of metamorphosis and the use of inert food.

A similar approach was used by Cañavate et al. (2007) to assess the effect of light on the development of sole larvae with or without adding $\beta$-carotene-rich Dunaliella salina. SOD, CAT, t-GPX and MDA were used as biomarkers. Growth and survival after metamorphosis were unaffected by light or D. salina. Light affects CAT and t-GPX throughout development but does not affect MDA, and SOD is only affected in metamorphosis. D. salina does not affect SOD, CAT or t-GPX and no interaction with light intensity was found. MDA lowers significantly only when $D$. salina is added, and its effect was found only in metamorphosing larvae, whose MDA levels are much higher than in earlier stages. These results confirm the antiperoxidative effect of $\beta$-carotene from live algae in the larval rearing process.

\subsection{The Pleurogene project}

After the initial studies on the growth and reproduction of the Senegalese sole, "Genoma España" and "Genome Canada" promoted the "Pleurogene" project, in order to develop new technology to assess gene and protein expression during the reproduction and breeding of two flatfish, Senegalese sole and Atlantic halibut. The project [http://www.genes.org] aimed to improve basic knowledge of reproduction, larval development and survival, and had de following objectives: 1) Establishment of an EST database and shotgun proteome analysis; 2) Construction of a microarray for high-throughput analysis of gene expression; 3) Construction of genetic linkage map; 4) Development of methods for gene expression profiling through laser capture microdissection RNA; 5) Identification of changes in gene expression during gamete development and maturation; 6) Genomic analysis of sex determination and differentiation; 7) Determination of the pattern of gene expression during larval metamorphosis, the ontogeny of the gastrointestinal tract and the effects of dietary treatments; and 8) Development of E-mold, an integrative bioinformatics platform for genomic, proteomic and morphological information from flatfish.

The Pleurogene project developed genomic and proteomic tools to help achieve these goals (Douglas et al., 2007; Cerdà et al., 2008), and also had the following major research results: 1) Development of genomics tools for the Senegalese sole, including 10 different cDNA libraries from adult and larvae tissues and 1 normalised multi-tissue library, 10,300 new sole EST sequences and nearly 500 peptides, and a sole oligonucleotide microarray with probes to detect 4550 different RNAs; 2) Development of a hormone treatment to increase sperm motility in sole; 3) Generation of a sole genetic linkage map; 4) Development of a progeny test or paternity kit; 5) Development of indirect approaches for sex control; 6) Production of recombinant gonadotropin hormone; 7) Generation of gene and protein expression maps associated to larval development, metamorphosis, and nutrition; 8) Generation of gene and protein expression maps of testes producing high quality sperm; 9) Generation of gene expression maps for sexual differentiation and maturation; and 10) Development of the "Solea-mold" that allows for new data to be included, in silico experiments to be performed, and comparative studies to be undertaken. 


\section{3. "Classic" biomarkers versus "omics" methodologies}

\subsection{Assessing pollution effects in fish}

After the initial studies of the UCO group, the use of "classic" biomarkers became increasingly popular to assess the effects of pollutants on fish. One example was the "Prestige" oil spill in November 2002 off the Galician coast (NW Spain). Due to the heavy nature of the crude oil and its low solubility in sea water, its dispersion was low and it remained in situ in oil patches adhered to rocks and sediments. The biological effects of these oil patches were tested in S. aurata (Morales-Caselles et al., 2006), using MT levels, EROD activity and histology as biomarkers, without significant results. Biomarkers including CAT, GSHPx, GSSGrase and DT-diaphorase, AcChE, CbE, GST and MDA were also analysed in S. senegalensis, with modest alterations (Solé et al., 2008).

Antioxidative and phase II and III biotransforming enzymes were used to follow the effects of linear alkylbenzene sulphonates in sole via an in vivo continuous-flow assay (AlvarezMuñoz et al., 2007) that was also used in S. aurata and S. senegalensis to assess the toxicity of sediments from littoral areas in northern and southern Spain (Jiménez-Tenorio et al., 2007), using MTs, EROD and histopathology. Jimenez-Tenorio et al. (2008) assessed the sediment toxicity caused in S. senegalensis by acute or chronic spills using histopathology, EROD and GST as biomarkers. Oxidative stress biomarkers and PAH contents were studied in Huelva soles near a petrochemical plant (Oliva et al., 2010). Significant correlations were found among the levels of GST, GPx and CAT, hepatic levels of PAH metabolites and PAH contents in sediments.

The effect of waterborne copper $(\mathrm{Cu})$ was studied in $S$. senegalensis in static conditions (Fonseca et al., 2009) by assessing the following characteristics: biomarkers such as MTs or MDA, mass indices, and biochemical condition indices such as the RNA/DNA ratio and the lipid and protein content. $\mathrm{Cu}$ triggers a biomarker response and lowers growth and condition, without changes in morphometric indices. Decreased condition shows that lipid reserves enable fish to respond to toxicity and to maintain growth and protein synthesis, although with lower rates than control fish.

The effects of Mexel ${ }^{\circledR 4} 32$ and $\mathrm{NaClO}$ antifoulings were studied in S. senegalensis by assessing osmolality, $\mathrm{Na}^{+} / \mathrm{K}^{+}$-ATPase, stress, histology, oxidative damage, antioxidant defences and detoxification (López-Galindo et al., 2010a,b). NaClO increases plasma cortisol, glucose and lactate after an acute stress, with a later recovery. Gill GST and AChE are sensitive to $\mathrm{NaClO}$. Hepatic markers initially respond to $\mathrm{NaClO}$ but longer exposures are toxic. Mexel ${ }^{\circledR} 432$ initially increases cortisol, which later returns to basal values, but glucose, lactate and triglycerides decresase. Gills have a lowered $\mathrm{Na}^{+}, \mathrm{K}^{+}$-ATPase activity, causing an imbalance in osmoregulation. Moderate changes are found in KAT, GSSGrase and GPX but not in MDA, GST or CbE. A multi-biomarker approach was used in Dicentrarchus labrax, S. senegalensis and Pomatoschistus microps, from the Aveiro and Tejo (Portugal) estuaries (Fonseca et al., 2011), which were affected by anthropic activities, without highly significant results.

Detection of DNA damage by biomarkers for genotoxicity was used in S. senegalensis (Costa et al., 2008a) exposed to sediments from three Sado Estuary (W Portugal) sites. The two blood parameters used were erythrocyte nuclear abnormalities (ENA) and DNA strandbreaks (DNA-SB). The levels of metals, PAHs, PCBs and DDTs were determined in the 
sediments. Scarcely polluted sediments are weaker inducers of genotoxic damage, whereas those under urban, industrial or agricultural influences significantly increase ENA and DNA-SB. A strong correlation exists between PAH and PCB content and genotoxicity, while metals have a weaker correlation. In a parallel study, $S$. senegalensis were exposed to Sado Estuary sediments (Costa et al., 2008b). Livers had more histological lesions than gills, and sediments contaminated by organics caused more damage to both organs than those contaminated by metals. Two "classic" biomarkers, MT and CYP1A, were also assessed. Lethality and biomarker responses do not linearly depend on the cumulative levels of contaminants but rather of their bioavailability and synergistic effects (Costa et al., 2009). In a parallel study, exposure to contaminated sediments induced DNA fragmentation and clastogenesis (Costa et al., 2011). Still, the most contaminated sediment revealed an antagonistic effect between metals and organics, enhanced by higher bioavailability. The laboratory assay caused a more pronounced increase in ENA, whereas a significant increase in DNA-SB exists in field-tested fish exposed to reference sediment.

\subsection{The advent of "omics" methodologies}

In contrast to the "classic" biomarker strategy, "omics" approaches, plus in vitro and in silico methods, are becoming a powerful multidisciplinary strategy. Their use is still at an early stage because most popular bioindicators are poorly represented in gene/protein sequence databases (Ruiz-Laguna et al., 2006; González-Fernández et al., 2008). Omics includes genomics to study DNA variations, transcriptomics for genome-wide characterisation of gene expression by measuring mRNAs, proteomics to assess the cell and tissue-wide expression of proteins, and metabolomics for global assessment of metabolite concentrations. These technologies provide detailed molecular information that helps to identify response pathways and to define mechanisms and modes of action without requiring previous knowledge. In 2003, the UCO group began a search for new biomarkers through the use of "omics" methods, which allowed the study of the Aznalcóllar spill and the status of Doñana National Park and its surroundings (SW Spain). These studies were collected in the following publications, listed here by publication date: Rodriguez-Ortega et al. (2002, 2003), Ruiz-Laguna et al. (2005, 2006), Bonilla-Valverde et al. (2004), López-Barea \& Gómez-Ariza (2006), Romero-Ruiz et al. (2006), Montes-Nieto et al. (2007, 2010), Vioque-Fernández et al. (2007a, 2007b, 2009a, 2009b), González-Fernández et al. (2008), Abril et al. (2011), and Pueyo et al. (2011).

All organisms are adapted to certain extracellular salinity ranges. Osmoregulatory mechanisms are central to adaptation. Osmotic stress was studied in tilapia Oreochromis mossambicus, spiny dogfish shark Squalus acanthias, and an intertidal sponge Tetilla mutabilis, by genomics and proteomics methods (Kültz et al., 2007). SSH, RACE-PCR and proteomics allowed the identification of genes and proteins involved in adaptation to salinity or other environmental stresses. Algorithms based on sequence homology searches (MSBLASTP2) are powerful tools for protein identification. Gene ontology and pathway analysis can subsequently use identified genes and proteins for modelling molecular mechanisms of environmental adaptation. The dependence on information about biochemical pathways and gene ontology databases for model species is a severe barrier for work with non-model species. To minimise this dependence, focusing on a single biological process is key when applying "omics" methods to non-model organisms. 
Environmental metabolomics allows for the characterisation of the metabolism of organisms from the natural environment and of those reared under laboratory conditions. Viant (2007) used this approach to characterise the responses of organisms to natural and anthropogenic stressors, discussing the challenges of measuring metabolites and highlighting the dynamic nature of the metabolome, whose variability is a challenge in environmental studies. The normal metabolic operating range (NMOR) is defined as the region in metabolic space in which $95 \%$ of individuals reside, and stress is a deviation from NMOR. The importance of genotypic and phenotypic anchoring (e.g., knowing species, gender, and age) is emphasised to facilitate the interpretation of multivariate metabolomics data.

An NRC-UK sponsored international consortium from government agencies, academia and industry in Canada, Japan, the UK, and the USA was carried out on fish toxicogenomics (Van Aggelen et al., 2010). The following three topics were addressed: progress in ecotoxicogenomics, perspectives on roadblocks for practical implementation of toxicogenomics into risk assessment, and dealing with variability in data sets. Although examples of successful application of "omic" technologies were identified, it is critical to perform studies that relate molecular changes to ecologically adverse outcomes. Although there are hurdles to pass on the road to regulatory acceptance, "omics" are already useful for elucidating modes of action of toxicants and can contribute to the risk assessment process as part of a weight-of-evidence approach.

A qRT-PCR approach was used to assess how Lactobacillus rhamnosus IMC 501 added to Amphiprion ocellaris larvae, alters development, and also to study the responses after probiotic exposure (Avella et al., 2010). Larvae and juveniles had 2-fold higher weight after probiotics were supplied. Metamorphosis occurs 3 days early, and factors involved in growth and development (I-l GF I/II, myostatin, PPAR $\alpha / \beta$, vitamin D receptor $\alpha$, and retinoic acid receptor $\gamma$ ) have higher gene expression. Probiotics lessen the severity of the general stress response as demonstrated by lower levels of glucocorticoid receptor and 70$\mathrm{kDa}$ HSP expression. Improved development of the skeletal head was also found, with 10$20 \%$ less deformities in probiotic-treated juveniles.

"Omics" have also been used in chemical screening and perturbation studies in zebrafish (Sukardi et al., 2010). Pharmacological efficacy and selectivity have been evaluated by chemical-induced phenotypic effects, although this has limitations in the identification of action mechanisms. "Omics" also facilitates the translatability of zebrafish studies across species by comparing conserved chemically induced responses. Thus, De Wit et al. (2010) characterised the estrogenic and metabolic effects of $17 \alpha$-ethinylestradiol (EE2) in D. rerio, following the concern regarding the effects of endocrine-disrupting compounds. Oligo microarrays, with 3479 zebrafish-specific oligos, were used to generate differential gene expression levels, and proteomic responses were evaluated by DIGE and MALDI-TOF/TOF. Assessment of the differentially expressed transcripts and proteins showed that both individual platforms could profile clear estrogenic interference and multiple metabolismrelated effects and stress responses. Cross-comparison of transcriptomics and proteomics datasets have limited concordance, but a revision of the results shows that transcriptional effects project at the protein level as downstream effects of the affected signalling pathways.

Public databases of coexpressed gene sets are valuable resources for many studies, including gene targeting for functional identification and investigations of regulatory mechanisms or protein-protein interactions. While coexpressed gene databases are highly popular in plant 
biology, those with animal data are limited due to the lower reliability of coexpression data. The COXPRESdb (http://coxpresdb.jp) represents the coexpression relationship in humans and mouse (Obayashi \& Kinoshita, 2011). Updates focusing on enhancing the reliability of gene coexpression data in animals have been reported. A new coexpression measure, Mutual Rank, has been implemented, and five other animal species, such as the rat, chicken, zebrafish, fly and nematode, were included to assess the conservation of coexpression. In addition, different layers of "omics" data have been added into the integrated network of genes. Functioning as a gene network representation, COXPRESdb can help researchers to clarify the functional and regulatory networks of genes in a broad array of animal species.

\section{Transcriptomic studies in Solea senegalensis}

Cultivation of the Senegalese sole is hampered by its sensitivity to different stresses and infectious diseases that can cause high mortality. Consequently, there is a need to identify sole genes responsive to stress, infections and pollutants in order to improve productivity, management and fish welfare. Transcriptomic responses of sole stimulated with lipopolysaccharide (LPS), a mimetic of bacterial infections, and copper sulphate, a zoosanitary compound, were studied by different experimental and methodological approaches, such as SSH libraries, DNA microarrays and real-time qRT-PCR (Prieto-Álamo et al., 2009; Osuna-Jiménez et al., 2009).

\subsection{SSH libraries}

The construction of subtractive libraries in S. senegalensis allowed the identification of differentially expressed genes in response to LPS in the head-kidney, a hematopoietic and lymphoid organ involved in immune response and to $\mathrm{CuSO}_{4}$ in the liver, a central metabolic organ in xenobiotic detoxification and in the defence system (Prieto-Álamo et al., 2009). In both cases, forward (F) and reverse (R) libraries were designed to obtain clones of genes that were up- or down-regulated in response to LPS of $\mathrm{CuSO}_{4}$ relative to the PBS control. To offset inter-individual variations and temporal differences in the responses, the libraries were constructed with total RNA from pooled head-kidney or liver ( $\geq 10$ fish/condition) of soles treated with LPS or $\mathrm{CuSO}_{4}$ for 6 and $24 \mathrm{~h}$. Four hundred sixty clones were sequenced and the products of the ESTs were identified by comparison with the open access databases. A total of 222 unique sequences were detected, and 185 were identified as related to major physiological functions (Table 1).

A high percentage of identified ESTs were related to immune response (Figure 1). Their presence in a sole head-kidney library stimulated with LPS agreed with the immune role of this organ and the immunostimulating effects of LPS (Swain et al., 2008). The number of genes classified as being immune-related was even larger in the liver than in the headkidney. Most of these immune-related ESTs coded for acute phase proteins (e.g., lysozyme, coagulation factors, proteinase inhibitors, complement components, and $\mathrm{Fe}$ transport/homeostasis proteins) according to several genomics studies indicating that, in teleost, the liver is an important source of immune transcripts (Ewart et al., 2005), mediating a powerful acute phase response (Bayne \& Gerwick, 2001). In addition, these results supported the capacity of $\mathrm{Cu}$ (like other metals) to alter immunological competence, in agreement with a report showing $\mathrm{Cu}$ up-regulation of the cytokine TGF- $\beta$ in striped bass (Geist et al., 2007). 


\begin{tabular}{|lccc|}
\hline & LPS (head-kidney) & CuSO $_{4}$ (liver) \\
\cline { 2 - 2 } Number of clones sequenced & 231 & 229 \\
Number of clones analysed & 222 & $211 \pm 168$ & 226 \\
Average sequence length (bp) & a & 133 & $414 \pm 155$ \\
Number of unique ESTs & 62 & 89 \\
Up-regulated ESTs & 49 & 48 \\
\multicolumn{1}{c}{ Identified ESTs } & 13 & 44 \\
Non-identified ESTs & 71 & 4 \\
Down-regulated ESTs & 58 & 41 \\
\multicolumn{1}{c}{ Identified ESTs } & 13 & 34 \\
\hline
\end{tabular}

Table 1. Characteristics of the sole SSH libraries and sequences. aMean \pm SEM

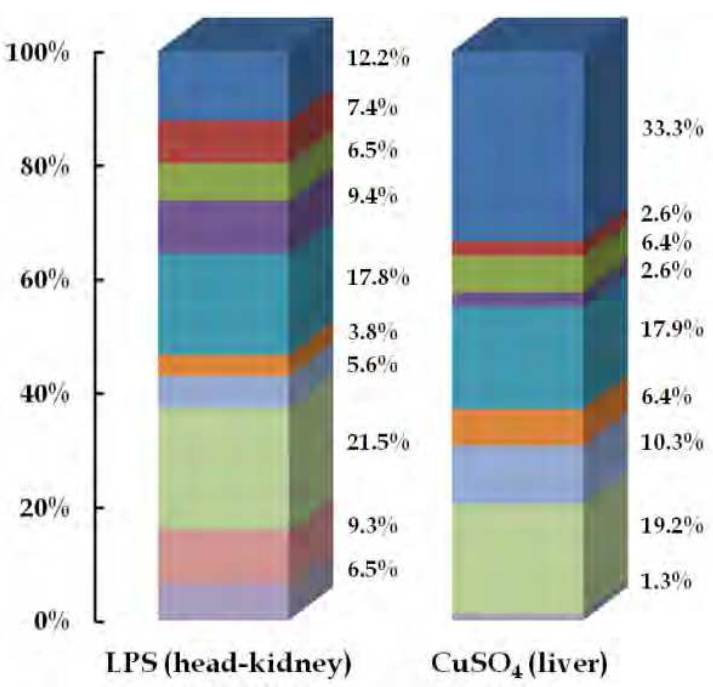

\begin{tabular}{|c|}
\hline : Immune response \\
\hline EResponse to stimulus \\
\hline a Cell signaling \\
\hline$=$ Transcription/translation \\
\hline - Metabolism \\
\hline Proteases \\
\hline in Transport \\
\hline Ribosomal proteins \\
\hline - Cellular and chromosomal structures \\
\hline e Others (unknown functions) \\
\hline
\end{tabular}

Fig. 1. Functional classification of unique ESTs obtained in SSH libraries from LPS or $\mathrm{CuSO}_{4}{ }^{-}$ treated soles. "Others" indicates genes that had significant identities to databases entries of unknown function.

Genes coding for products involved in osmoregulation and nitrogen excretion (e.g., liver angiotensinogen, sodium potassium ATPase beta subunit, kininogen 1, angiotensin I converting enzyme 1, and alanine-glyoxylate aminotransferase 2 -like) were also identified in libraries from the livers of $\mathrm{CuSO}_{4}$-treated soles, in agreement with the previously reported effects of copper on osmoregulation, acid-base balance and nitrogen excretion (e.g., Blanchard \& Grosell, 2006; Evans et al., 2005).

\subsection{DNA microarrays}

The microarray developed for the European flounder Platichthys flessus (GENIPOL platform, Williams et al., 2006) had been used to assess hepatic gene expression of many species of flatfish, confirming that heterologous microarray analyses between closely related species is 
a suitable approach (Cohen et al., 2007). This platform turned out a very useful tool for analysing the transcriptional expression of $S$. senegalensis.

First, the hepatic response of soles exposed to $\mathrm{CuSO}_{4}$ or LPS was studied using pooled samples. Statistical analyses showed that 405 genes were differentially expressed after $\mathrm{Cu}$ treatment at $6 \mathrm{~h}, 468$ with Cu at $24 \mathrm{~h}, 271$ with LPS at $6 \mathrm{~h}$ and 664 with LPS at $24 \mathrm{~h}$ (Table 2).



Table 2. Number of differentially expressed genes in S. senegalensis liver in response to LPS or $\mathrm{CuSO}_{4}$ treatments that were identified by heterologous DNA microarrays.

The functional analysis of the results (Blast2GO software) permitted the identification of response-specific genes to $\mathrm{CuSO}_{4}$ (cell junction and cell signalling), to LPS (glutathione transferase and immune response) or to both treatments (immune response, digestive enzymes, unfolded protein binding, intracellular transport and secretion, and proteasome) (Table 3). This way, the functional category cell junction was statistically significantly overrepresented amongst the genes induced by copper at $6 \mathrm{~h}$. This term grouped genes related to cellular adhesion, such those coding for claudins (CLDN26) and genes related to cell signalling, such as GIT2 that encodes G-protein-coupled receptor kinase interactor 2, which is in agreement with the ability of copper to alter the tight junction permeability in human intestinal mucosa (Ferruzza et al., 2002). Glutathione-S-transferases were more prevalent amongst the transcripts down-regulated by LPS at $24 \mathrm{~h}$. The capacity of LPS and bacterial infection to down-regulate biotransformation activities such as GSTs has been described in a number of fish species (Reynaud et al., 2008). As shown in Table 3, genes related to the immune response were specifically induced by LPS. These included the antimicrobial peptide hepcidin (HAMP), TNFa-induced protein 9 (TNFAIP9), cytokines (IL8, IL25) and chemotaxins (LECT2).

Other immune-related genes were induced by both LPS and $\mathrm{CuSO}_{4}$ treatments. This is the case for classic piscine acute phase proteins like haptoglobin (HP) or C7 (Bayne \& Gerwick, 2001). C7 is a component of the complement system, whose up-regulation by copper is in line with complement proteins being engaged in novel biological functions distinct from their wellestablished role in innate immunity (Mastellos et al., 2005). Although soles were fasted prior to and during the experiments, digestive enzymes such as trypsin (PRSS2), chymotripsin (CTRB), elastase (ELA4) and carboxypetidase A (CPA1) and B (CPA2) were down-regulated in response to both treatments. This might be due to a general stress caused by the treatment (Auslander et al., 2008). Furthermore, LPS and copper treatments resulted in the up-regulation of genes encoding unfolded protein-binding, which are induced in fish in response to different kinds of stress conditions (e.g., bacterial infection or exposure to heavy metals) (Basu et al., 2002), intracellular transport and secretion, in order to accommodate the rapid onset of cytokine secretion and for membrane traffic associated with the phenotypic changes of immune activation (Pagan et al., 2003), and proteasomal proteins in agreement with previous results in mammalian cells (Qureshi et al., 2003; Fernandes et al., 2006). 


\begin{tabular}{|c|c|c|c|}
\hline & Response to LPS & Response to $\mathrm{CuSO}_{4}$ & Selected genes \\
\hline Cell junctions & --- & Up-regulation & CLDN26, GIT2 \\
\hline $\begin{array}{l}\text { Glutathione-S- } \\
\text { transferases }\end{array}$ & Down-regulation & --- & $\begin{array}{l}\text { GST-A, GST1, } \\
\text { GST3 }\end{array}$ \\
\hline \multirow[t]{2}{*}{ Immune response } & Up-regulation & --- & $\begin{array}{l}\text { HAMP, TNFAIP9, } \\
\text { IL8, IL25, LECT2 }\end{array}$ \\
\hline & Up-regulation & Up-regulation & $\mathrm{C} 7, \mathrm{HP}$ \\
\hline Digestive enzymes & Down-regulation & Down-regulation & $\begin{array}{l}\text { PRSS2, CTRB, } \\
\text { ELA4, CPA1, CPA2 }\end{array}$ \\
\hline $\begin{array}{l}\text { Unfolded protein } \\
\text { binding }\end{array}$ & Up-regulation & Up-regulation & GP96, HSP70 \\
\hline $\begin{array}{l}\text { Intracellular } \\
\text { transport/secretion }\end{array}$ & Up-regulation & Up-regulation & $\begin{array}{l}\text { ARF5, TMED7, } \\
\text { SEC22 }\end{array}$ \\
\hline Proteasome & Up-regulation & Up-regulation & PMSD3, MSUG1 \\
\hline
\end{tabular}

Table 3. Selected genes that were significantly differentially expressed in the liver of $S$. senegalensis during $\mathrm{LPS}$ or $\mathrm{CuSO}_{4}$ treatments.

Because the GENIPOL cDNA microarray was constructed from ESTs derived from flounder liver and had been used in studies of hepatic expression (Cohen et al., 2007; Williams et al., 2006, 2007, 2008), we investigated whether this platform would be valid for analysing the transcriptional response in the head-kidney. To this end, the GENIPOL microarray was used to compare the basal transcriptional expression in the Solea senegalensis head-kidney and liver. We determined that 1004 genes were statistically differentially expressed in both organs: 418 transcripts were more abundant in the liver than in the head-kidney and 586 transcripts were more abundant in the head-kidney than in the liver. Thus, although the microarray was constructed with hepatic ESTs, the number of genes identified as overexpressed is similar in both organs, though slightly higher in the head-kidney than in the liver. The analysis of transcriptional patterns showed that the most represented biological processes amongst the genes up-regulated in the liver in comparison with the head-kidney were those involved in innate immune response, digestion, lipid transport, and monooxygenase activity (Table 4). The category "innate immune response" grouped genes coding for acute phase proteins because, as has been previously discussed, the liver is the main source of these plasmatic proteins. Amongst the genes related to lipid transport that were particularly remarkable were those coding for several apolipoproteins. The term "monooxygenase activity" encompassed genes belonging to the cytochrome P450 family, in agreement with what is known about the detoxifying capacity and the biotransformation activity of the liver in teleosts (Thorgaard et al., 2002).

Functional terms over-represented in the list of transcripts that were more abundant in the head-kidney than in the liver related to cellular division and protein turnover (protein degradation and the proteasome and ribosomal proteins), among others (Table 5). These results agree with the role of the head-kidney as a major haematopoietic organ in teleosts and with its function as a secondary lymphoid organ in the clearance of soluble and particulate antigens from circulation (Whyte, 2007). It is worth noting that when the lists of genes that are up-regulated in both organs were compared, two sequences corresponding to 
Innate immune response
alpha-1-antitrypsin, alpha-2-macroglobulin, anticoagulant protein C precursor, coagulation factor
VIIc, chemotaxin, complement component C3, complement component C8, complement
component C9, complement regulatory plasma protein, fibrinogen alpha, fibrinogen beta chain
precursor, fibrinogen gamma chain precursor, haptoglobin, hepcidin precursor, interleukin 8
precursor, kininogen 1, plasma protease C1 inhibitor precursor, prothrombin precursor, putative
complement factor, transferrin
Digestive enzymes
chymotrypsinogen 1, chymotrypsinogen 2, trypsinogen 2 precursor
Lipid transport
apolipoprotein A-I, apolipoprotein A-IV, apolipoprotein C-I precursor, apolipoprotein E,
apolipoprotein H, 14kDa apolipoprotein, fatty acid-binding protein
Monooxygenase activity
$\quad$ cytochrome P450 2F2, cytochrome P450 2X, cytochrome P450 3A, cytochrome P450 3A45,
cytochrome P450 8B1, cytochrome P450 monooxygenase

Table 4. Selected genes up-regulated in the liver in comparison with the head-kidney in $S$. senegalensis.

\footnotetext{
Cellular division/cytoskeleton

alpha-tubulin, actin-related protein 3 homolog, actin related protein $2 / 3$ complex subunit 4 , betaactin, cofilin 2, coronin 1A, lamin B1, microtubule-based motor protein, mitotic spindle assembly checkpoint protein, myosin regulatory light chain 2, nuclear movement protein PNUDC, thymosin beta- 4

\section{Protein degradation/proteasome}

polyubiquitin, proteasome alpha 1 subunit isoform 2, proteasome (prosome, macropain) subunit alpha type 7, proteasome beta-subunit $\mathrm{C} 5$, proteasome subunit beta type 3 , proteasome (prosome, macropain) subunit beta type 5, proteasome 26S ATPase subunit 5, proteasome subunit N3, ubiquitin carboxyl-terminal hydrolase isozyme L, ubiquitin specific protease 9

\section{Ribosomal proteins}

40 S ribosomal protein S3a, 40S ribosomal protein S4, 60S ribosomal protein L3, 60S ribosomal protein L4, 60S ribosomal protein L13
}

Table 5. Selected genes up-regulated in the head-kidney in comparison with the liver in $S$. senegalensis.

the GAPDH (glyceraldehyde 3-phosphate dehydrogenase) gene, but with different expression patterns, were detected. The first of these sequences was more abundant in the liver, while the second was prevalent in the head-kidney. Solea senegalensis possesses two different GADPH paralogous genes that exhibit different tissue expression patterns, with GAPDH1 being more abundant in the liver and the GAPDH2 isoform more prevalent in the head-kidney (Manchado et al., 2007). A detailed analysis of the sequences detected in the microarray study revealed that these sequences match the two described isoforms. Altogether, these results demonstrated that the GENIPOL microarray platform was valid for analysing the transcriptional response of the sole head-kidney, discriminating between genes coding for transcripts with specific patterns of hepatic or renal expression. 
Consequently, the GENIPOL platform was used to assess the response to LPS in the headkidney. After $24 \mathrm{~h}$ of LPS treatment, a total of 224 genes was statistically differentially expressed in the head-kidney (117 up-regulated and 107 down-regulated). The functional analysis of the results revealed that the biological processes altered by LPS treatment in the head-kidney were very similar to those detected in the liver. Most notably amongst the up-regulated genes were the functional groups immune response, unfolded proteinbinding, intracellular transport/secretion and proteasome, and digestive enzymes in the list of down-regulated genes. In contrast, the glutathione transferases category, whose transcript levels were down-regulated by LPS in the liver, was not affected in the headkidney.

\subsection{Real-time qRT-PCR}

Although the determination of absolute transcript abundance (the exact number of molecules of a transcript in all samples of the study) is the only adequate procedure to accurately assess the expression of a gene (Prieto-Álamo et al., 2003), these kinds of studies are infrequent due to the experimental difficulties that impair this type of analysis. A set of more than 20 sole transcripts was selected for the quantification of their levels by this rigorous approach (Table 6) (Prieto-Álamo et al., 2009; Osuna-Jiménez et al., 2009), based on the physiological relevance of their products and on the magnitude and specificity of their responses.

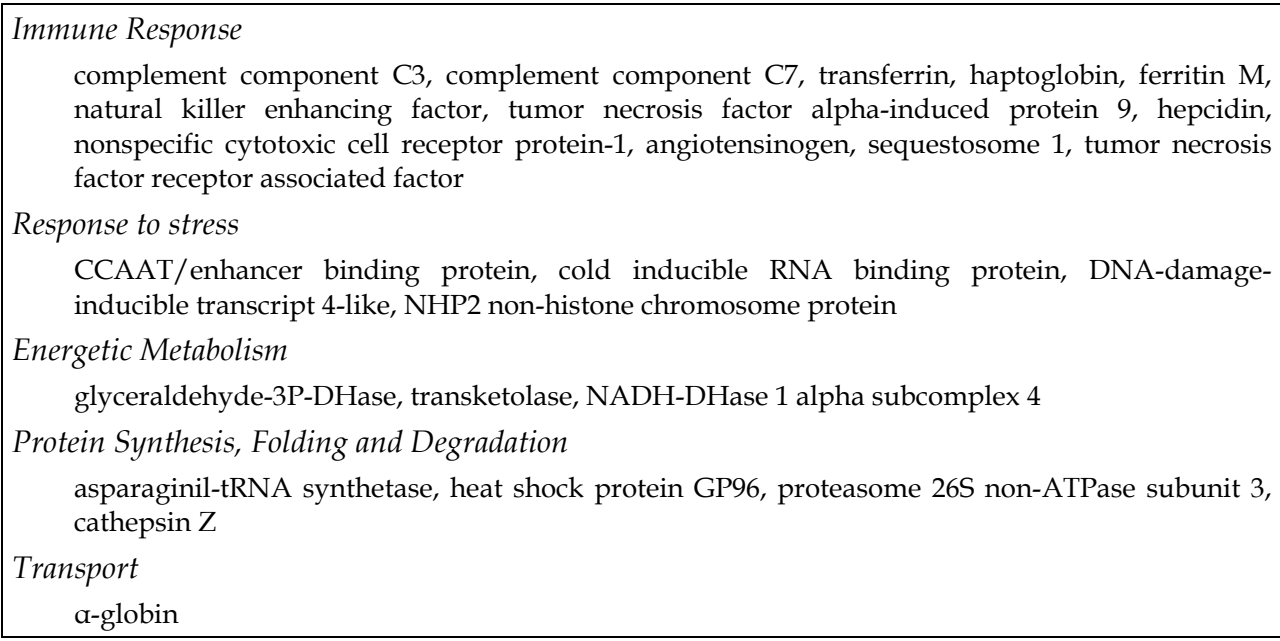

Table 6. Biological functions of proteins encoded by the sole transcripts selected to be validated by real-time qRT-PCR (Prieto-Álamo et al., 2009; Osuna-Jiménez et al., 2009).

The absolute quantification of the selected transcripts was not limited to the samples used for global analysis, but rather extended to samples coming from different individuals, organs, treatments and exposure times. Consequently, this gene-to-gene analysis provided valuable additional information on transcriptional expression patterns of the selected genes. Individual quantification is also mandatory to prevent biased interpretations of specimens with abnormal expression levels. The absolute real-time qRT-PCR on individual samples 
demonstrated that inter-individual variations of most examined transcripts in treated animals was in the range of that in control fish, indicating similar susceptibility to LPS or $\mathrm{CuSO}_{4}$ challenge among individuals. The qRT-PCR quantifications confirm, in general, the results obtained with the subtractive libraries and the DNA microarrays. As expected, substantial differences in abundance were found depending on the transcript and tissue examined. In general, each transcript displayed a characteristic expression profile, distinguishing between constitutive or up-/down-regulated, early or late responsive, stressor-specific or not, etc., as a function of the organ analysed.

\section{Proteomics studies of GBD}

Fish reared in earth ponds are eventually affected by Gas Bubble Disease (GBD) outbreaks if ponds are not correctly handled, particularly under high temperature and radiation conditions. GBD is a non-infectious pathology occurring when the partial pressures of atmospheric gases in solution exceed their respective partial pressures in the atmosphere. GBD was initially observed in farmed species, although outbreaks in wild fish, both freshwater and marine animals, have also been reported. GBD can have serious adverse economic repercussions in fish cultures by reducing productivity and the commercial value of the fish as well as the farm profitability. Thus, the development of biomarkers responsive to hyperoxia stress would be a valuable tool to apply in systems where oxygen supersaturation might be possible, and would also contribute to basic knowledge of oxidative stress. Oxygen supplementation is a common practice in intensive fish farming, in order to allow high density cultivation while reducing the amount of water demanded in aquaculture facilities. It is also required during fish transportation. In intensive aquaculture, the use of oxygen is regulated by sophisticated mechanisms to keep its concentration close to desired values. However, in open ponds, the likelihood of oxygen supersaturation conditions is higher, because primary producers are in a high nutrient environment, occasionally combined with high temperature and radiation. Photosynthetic oxygen overproduction is a factor of concern for pond aquaculture, particularly when species such as sole, which exhibit nocturnal and benthic habits, are considered. These features complicate water management compared to pond operation in pelagic fish farming.

Environmental and physicochemical conditions inducing hyperoxia, such as radiation, temperature and dissolved $\mathrm{O}_{2}$, were monitored in two independent land-based ponds of an aquaculture research centre (IFAPA Centro El Toruño, Puerto de Santa María, Cádiz, Spain) in which $S$. senegalensis were reared, after a GBD outbreak was detected in some of these animals (Salas-Leyton et al., 2009). Fig. 2 (upper) shows the appearance of the earth pond used as control $\left(100 \mathrm{~m}^{2}\right.$, water renewed 4-fold/day) and of that in which GBD developed $\left(900 \mathrm{~m}^{2}\right.$, water unrenewed) in which algal blooms can be observed at its border. As shown in Fig. 2 (centre), the dissolved oxygen profile detected in the hyperoxic earth pond was typical of that in environments dominated by macroalgal biomass and high photosynthetic activity, where extreme oxygen levels are reached during a great part of the daily cycle (including night hours), always above saturation without a desaturation phase. As shown in Fig. 2 (lower), the following typical GBD symptoms were detected in fish from this pond: exophthalmia caused by retrobulbar bubbles (A), subcutaneous emphysemas, obstruction of gill lamellas (B), big bubbles located at caudal (C) and dorsal 
(I)


Fig. 2. Earth ponds, dissolved oxygen monitoring and visible symptoms in GBD-affected soles. (I) The experiments were carried out in two independent land-based ponds, one a $900 \mathrm{~m}^{2}$ rectangular pond where oxygen supersaturation developed spontaneously, named the GBD pond (right) and the other a $100 \mathrm{~m}^{2}$ control pond (left) in which water was renewed four times per day. (II) Dissolved oxygen was simultaneously monitored throughout the daily cycle in both the control (green line) and GBD ponds (red line). (III) Visible symptoms observed in GBD-affected soles included the following: exophthalmia caused by retrobulbar bubbles (A), a bubble obstructing a gill lamella (B), and a large bubble located at caudal fin (C). 
fins, haemorrhages, anomalous swimming accompanied by loss of orientation, nearlethargy status and individual isolation were the main effects of $\mathrm{O}_{2}$ supersaturation (SalasLeyton et al., 2009).

Under the described aquaculture conditions, a parallel proteomic study was carried out in search of protein alteration patterns that might be used as potential new and unbiased biomarkers of hyperoxic stress (Fig. 3) (Salas-Leyton et al., 2009). The following three health statuses were studied in sole individuals: (1) healthy control fish, (2) GBD-affected but asymptomatic fish, and (3) GBD-affected fish with visible symptoms. Protein expression profiles were studied by 2-DE in cytosolic fractions of gills and livers. A total of 1,525 and 1,632 spots were detected in the four gill and liver gels, respectively, that were run in each of the three situations studied. Fig. 3 (upper) shows the master gels of cytosolic gill (left) and liver (right) proteins. A total of 205 protein spots were differentially expressed in the gills and 498 in the liver in each health status. Fig. 3 (middle) shows the number of spots which are present only, absent, increased or diminished in each of the studied conditions, and the total number of changes found. A significantly higher number of differentially expressed spots were found in GBD-affected soles, mainly in fish with visible symptoms. Of these, 25 spots in the gills and 23 in the liver were selected for identification using tandem mass spectrometry (nESI-IT MS/MS), de novo sequencing and a bioinformatics search. Fig. 3 (lower) shows the percentage of the relative intensity of each spot in each health status. Sequence tags were obtained from 9 (gills) and 5 (liver) of the selected spots, resulting in a total of 14 identified spots in the GBD status, which are indicated in Fig. 3 (lower).

Due to the central role of gills in oxygen exchange, the proteins identified in the gills of GBD-affected fish were, unsurprisingly, related to oxidative alteration of the cytoskeleton structure or function ( $\beta$-tubulin and $\beta$-actin), motility (light myosin chain and atropomyosin), regulatory pathways (calmodulin, Raf kinase inhibitor protein [RKIP]) and carbohydrate metabolism (glyceraldehyde 3-P dehydrogenase). The hyperoxia-linked effects of these proteins and higher-level responses, related to inflammatory response, apoptosis or cell death, or derived from alterations in the regulatory proteins, have been discussed in depth (Salas-Leyton et al., 2009). In gills, only RKIP was most intense in GBD-affected animals without symptoms, while the other seven identified proteins were most intense in GBD-affected fish with symptoms. Proteins identified in the liver were related to protein oxidative damages ( $\beta$-globin and fatty acid-binding protein $[\mathrm{FABP}])$, protection from oxidative stress (dicarbonyl/L-xylulose reductase and glycine $\mathrm{N}$ methyltransferase) and inflammatory response (complement component C3), in agreement with the predominant metabolic role of this organ. In the liver, only FABP was most intense in healthy fish, while the other four identified proteins were most intense in GBD-affected fish with visible symptoms. Approximately $50 \%$ of the identified proteins corresponded to "unusual" proteins not often found in proteomics screens, while the rest were preferential targets of oxidative stress. Most of these latter proteins were found as truncated forms of oxidised proteins that might trigger cellular defences against hyperoxygenation preceding GBD outbreaks. Some of the identified proteins might be considered to be good hyperoxia stress biomarkers and could be used in the earlywarning detection of GBD outbreaks. Massive proteomic approaches have been applied for the first time to the study of this non-infectious pathological condition, gas bubble disease, in fish. 
(I)

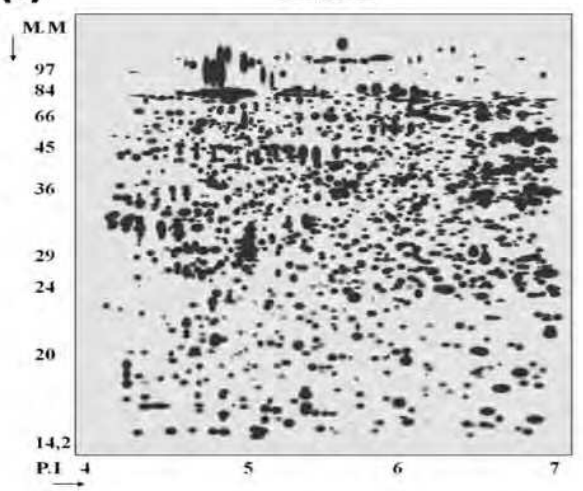

(II)

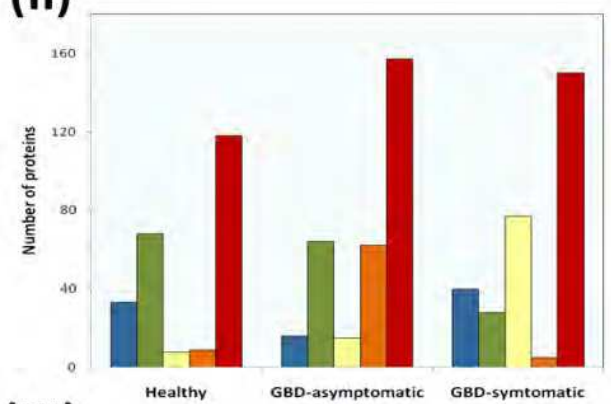

(III)



\section{LIVER}


GBD-asymptomatic GBD-symtomatic



Fig. 3. Proteomic study of GBD-affected juvenile soles after 2-DE of cytosolic gill (left) and liver (right) proteins. (I) Master gels. (II) Number of proteins showing distinct protein expression patterns in healthy, GBD-asymptomatic and GBD-symptomatic fish. Bars represent the number of protein spots present only ( $\square)$, absent ( $\square)$, increased ( ), diminished $(\square)$ and the total number of changes ( $\square$ ) found in each of the conditions. (III) Spots selected for possible identification by mass spectrometry analysis. Bars represent the percentage of the relative intensity of each spot in every status: healthy ( $\square)$, GBD-asymptomatic $(\square)$ and GBD-symptomatic ( $\square$ ) animals. Successfully identified proteins are highlighted. 


\section{Conclusions}

Given the economic importance of $S$. senegalensis, an aquaculture species that remains largely unexplored at the genomic level, the application of postgenomic methodologies provides results that may be highly relevant at a genetic, immunological and toxicological level, contributing to the improvement of management and welfare of this organism in aquaculture. The utility of high-throughput proteomic methods for unveiling the molecular basis of a cumbersome disease in aquaculture has been also demonstrated.

\section{Acknowledgments}

This work was funded by grants CTM2009-12858-C02 (Spanish Ministry of Science and Education), CYCE-00516 and P08-CVI-03829 (Innovation and Science Agency, Andalusian Government).

\section{References}

Abril, N.; Ruiz-Laguna, J.; Osuna-Jiménez, I.; Vioque-Fernández, A.; Fernández-Cisnal, R.; Chicano-Galvez, E.; Alhama, J.; López-Barea, J. \& Pueyo, C. (2011). Omic approaches in environmental issues. Journal of Toxicology and Environmental Health, Part A, 74: 1-19.

Alhama, J.; Romero-Ruiz, A. \& López-Barea, J. (2006). Metallothionein quantification in clams (Chamaelea gallina) by RP-HPLC and fluorescence detection after monobromobimane derivatization. Journal of Chromatography A, 1107, 52-58.

Alhama, J.; Romero-Ruiz, A.; Jebali, J. \& López-Barea, J. (2010). Total metallothionein quantification by reversed-phase high-performance liquid chromatography coupled to fluorescence detection after monobromobimane derivatization. In: Cadmium in the Environment, Parvau, R.G. (Ed.), 389-405, Nova Science Publishers, Inc., ISBN 978-1-60741-934-1, Hauppauge, NY, USA.

Álvarez-Muñoz, D.; Lara-Martin, P.A.; Blasco, J.; Gómez-Parra, A. \& González-Mazo, E. (2007). Presence, biotransformation and effects of sulfophenylcarboxilic acids in the benthic fish Solea senegalensis. Environment International, 33, 565-570.

Aragão, C.; Conceiçao, L.E.C.; Martins, D.; Rønnestad, I.; Gomes, E. \& Dinis, M.T. (2004a). A balanced dietary amino acid profile improves amino acid retention in post-larval Senegalese sole (Solea senegalensis). Aquaculture, 233, 293-304.

Aragão, C.; Conceiçao, L.E.C.; Fyhn, H.J. \& Dinis, M.T. (2004b). Estimated amino acid requirements during early ontogeny in fish with different life styles: gilthead seabream (Sparus aurata) and Senegalese sole (Solea senegalensis). Aquaculture, 242, 589-605.

Auslander, M.; Yudkovski, Y.; Chalifa-Caspi, V.; Herut, B.; Ophir, R.; Reinhardt, R.; Neumann, P.M. \& Tom, M. (2008). Pollution-affected fish hepatic transcriptome and its expression patterns on exposure to cadmium. Marine Biotechnology, (NY), 10(3), 250-261.

Avella, M.A.; Olivotto, I.; Silvi, S.; Place, A.R. \& Carnevalli, O. (2010). Effect of dietary probiotics on clownfish: a molecular approach to define how lactic bacteria modulate development in a marine fish. American Journal of Physiology. Regulatory, Integrative and Comparative Physiology, 298, R359-R371.

Basu, N.; Todgham, A.E.; Ackerman, P.A.; Bibeau, M.R.; Nakano, K.; Schulte, P.M. \& Iwama G.K. (2002). Heat shock protein genes and their functional significance in fish. Gene, 295(2), 173-183. 
Bayne, C.J. \& Gerwick, L. (2001). The acute phase response and innate immunity of fish. Developmental \& Comparative Immunology, 25(8-9), 725-743.

Blanchard, J. \& Grosell, M. (2006). Copper toxicity across salinities from freshwater to seawater in the euryhaline fish Fundulus heteroclitus: is copper an ionoregulatory toxicant in high salinities? Aquatic Toxicology, 80(2), 131-139.

Bonilla-Valverde, D.; Ruíz-Laguna, J.; Muñoz, A.; Ballesteros, J.; Lorenzo, F.; Gómez-Ariza, J.L. \& López-Barea, J. (2004). Evolution of biological effects of Aznalcollar mining spill in the Algerian mouse (Mus spretus) using biochemical biomarkers. Toxicology, 197: 123-138.

Cabrita, E.; Soares, F. \& Dinis, M.T. (2006). Characterization of Senegalese sole, Solea senegalensis, male broodstock in terms of sperm production and quality. Aquaculture, 261, 967-975.

Cánovas-Conesa, B.; Salas, E.; Alhama, J.; López-Barea, J. \& Cañavate J.P. (2007). Efecto de la densidad de cultivo sobre los biomarcadores bioquímicos y la carga energética en el lenguado senegalés (Solea senegalensis). In: Libro de Actas del XI Congreso Nacional Acuicultura, Cerviño, A.; Guerra, A. \& Pérez, C. (Eds.), 1463-1466, Universidad de Vigo, ISBN 978-84-611-9085-0, Vigo, España.

Cañavate, J.P. (2005). Potential of the Senegal sole Solea senegalensis Kaup, 1858 for marine aquaculture diversification. Boletín del Instituto Español de Oceanografía, 21, 147-154.

Cañavate, J.P.; Prieto, A.; Zerolo, R.; Solé, M.; Sarasquete, C. \& Fernández-Díaz, C. (2007). Effects of light intensity and addition of carotene rich Dunaliella salina live cells on growth and antioxidant activity of Solea senegalensis Kaup (1858) larval and metamorphic stages. Journal of Fish Biology, 71, 781-794.

Cerdà, J.; Mercadé, J.; Lozano, J.J.; Manchado, M.; Tingaud-Sequeira, A.; Astola, A.; Infante, C.; Halm, S.; Viñas, J.; Castellana, B.; Asensio, E.; Cañavate, P.; MartínezRodríguez, G.; Piferrer, F.; Planas, J.V.; Prat, F.; Yúfera, M.; Durany, O.; Subirada, F.; Rosell, E. \& Maes, T. (2008). Genomic resources for a commercial flatfish, the Senegalese sole (Solea senegalensis): ETS sequencing, oligo microarray design, and development of the Soleamold bioinformatic platform. BMC Genomics, 9, 508.

Cohen, R.; Chalifa-Caspi, V.; Williams, T.D.; Auslander, M.; George, S.G.; Chipman, J.K. \& Tom, M. (2007) Estimating the efficiency of fish cross-species cDNA microarray hybridization. Marine Biotechnology, 9, 491-499

COM/0511 (2002). Communication from the Commission on A Strategy for the Sustainable Development of European Aquaculture.

Conceiçao, L.E.C.; Grasdalen, H. \& Rønnestad, I. (2003). Amino acid requirements of fish larvae and post-larvae: new tools and recent findings. Aquaculture, 227, 221-232.

Conceiçao, L.E.C.; Ribeiro, L.; Engrola, S.; Aragão, C.; Morais, S.; Lacuisse, M.; Soares, F. \& Dinis, M.T. (2007). Nutritional physiology during development of Senegalese sole (Solea senegalensis). Aquaculture, 268, 64-81.

Costa, P.M.; Lobo, J.; Caeiro, S.; Martins, M.; Ferreira, A.M.; Caetano, M.; Vale, C.; DelValls, T.A. \& Costa, M.H. (2008a). Genotoxic damage in Solea senegalensis exposed to sediments form the Sado Estuary (Portugal): Effects of metallic and organic contaminants. Mutation Research, 654, 29-37.

Costa, P.M.; Diniz, M.S.; Caeiro, S.; Lobo, J.; Martins, M.; Ferreira, A.M.; Caetano, M.; Vale, C.; DelValls, T.A. \& Costa, M.H. (2008b). Histological markers in liver and gills of juvenile Solea senegalensis exposed to contaminated estuarine sediments: A weighted indices approach. Aquatic Toxicology, 92, 202-212.

Costa, P.M.; Caeiro, S.; Diniz, M.S.; Lobo, J.; Martins, M.; Ferreira, A.M.; Caetano, M.; Vale, C.; DelValls, T.A. \& Costa, M.H. (2009). Biochemical endpoints on juvenile Solea 
senegalensis exposed to estuarine sediments: the effects of contaminant mixtures on metallothionein and CYP1A induction. Ecotoxicology, 18, 988-1000.

Costa, P.M.; Neuparth, T.S.; Caeiro, S.; Lobo, J.; Martins, M.; Ferreira, A.M.; Caetano, M.; Vale, C.; DelValls, T.A. \& Costa, M.H. (2011). Assessment of the genotoxic potential of contaminated estuarine sediments in fish peripheral blood: Laboratory versus in situ studies. Environmental Research, 111, 25-36.

Cousinou, M.; Dorado, G. \& López-Barea, J. (1999). Amplification and cloning of cDNAs of cytochrome P4501A1 and metallothionein genes from Sparus aurata Linnaeus, 1758 and Liza aurata (Risso, 1810) by RACE-PCR. Boletín del Instituto Español de Oceanografía, 15, 473-484.

Cousinou. M.; Nilsen, B.; López-Barea, J. \& Dorado, G. (2000). New methods to use of fish cytochrome P4501A to assess marine organic pollutants. Science of Total Environment, 247, 213-225.

De Wit, M.; Keil, D.; van der Ven, K.; Vandamme, S.; Witters, E. \& De Coen, W. (2010). An integrated transcriptomic and proteomic approach characterizing estrogenic and metabolic effects of $17 \alpha$-ethinylestradiol in zebrafish (Danio rerio). General $\mathcal{E}$ Comparative Endocrinology, 167, 190-201.

Dias, J.; Yúfera, M.; Valente, L.M.P. \& Rema, P. (2010). Feed transit and apperent protein, phosphorous and energy digestibility of practical feed ingredients by Senegalese sole (Solea senegalensis). Aquaculture, 302, 94-99.

Diatchenko, L.; Lay, Y.F.; Campbell, A.P.; Chenchik, A.; Moqadam, F.; Huang, B.; Lukyanov, K.; Lukyanov, K.; Gurskaya, N.; Sverdlov, E.D. \& Siebert, P.D. (1996). Suppresion subtractive hybridization: A method for generating differentially regulated or tissue-specific cDNA probes and librairies. Proceedings of the National Academy of Sciences of the USA, 93, 6025-6030.

Dinis, M.T.; Ribero. L.; Soares, F. \& Sarasquete, C. (1999). A review on the cultivation potential of Solea senegalensis in Spain and Portugal. Aquaculture, 176, 27-38

Douglas, S.E.; Knickle, L.C.; Kimball, J. \& Reith, M.E. (2007). Comprehensive EST analysis of Atlantic halibut (Hippoglossus hippoglossus), a commercially relevant aquaculture species. BMC Genomics, 8, 144

Evans, D.H.; Piermarini, P.M. \& Choe, K.P. (2005). The multifunctional fish gill: dominant site of gas exchange, osmoregulation, acid-base regulation, and excretion of nitrogenous waste. Physiological Reviews, 85(1), 97-177.

Ewart, K.V.; Belanger, J.C.; Williams, J., Karakach, T.; Penny, S.; Tsoi, S.C.; Richards, R.C. \& Douglas, S.E. (2005). Identification of genes differentially expressed in Atlantic salmon (Salmo salar) in response to infection by Aeromonas salmonicida using cDNA microarray technology. Developmental \& Comparative Immunology, 29(4), 333-347.

FAO: Food and Agriculture Organization of the United Nations (2010). Aquaculture planning. Policy formulation and implementation of sustainable development. FAO Fisheries and Aquaculture Technical Paper 542. Rome FAO.

Fernandes, R.; Ramalho, J. \& Pereira, P. (2006). Oxidative stress upregulates ubiquitin proteasome pathway in retinal endothelial cells. Molecular Vision, 12, 1526-1535.

Fernández-Díaz, C.; Kopecka, J.; Cañavate, J.P.; Sarasquete, C. \& Solé, M. (2006). Variations on development and stress defences in Solea senegalensis larvae fed on live and microencapsulated diets. Aquaculture, 251, 573-584.

Ferruzza, S.V; Scacchi, M.; Scarino, M.L. \& Sambuy, Y. (2002). Iron and copper alter tight junction permeability in human intestinal Caco-2 cells by distinct mechanisms. Toxicology In Vitro, 16(4), 399-404. 
Fonseca, V.; Serafim, A.; Company, R.; Bebianno, M.J.; \& Cabral, H.N. (2009) Effect of copper on growth, condition indices and biomarker response in juvenile sole Solea senegalensis. Scientia Marina, 73, 51-58.

Fonseca, V.; Franca, S.; Serafim, A.; Company, R.; Lopes, B.; Bebianno, M.J.; \& Cabral, H.N. (2011) Multi-biomarker response to estuarine habitat contamination in three fish species: Dicentrarchus labrax, Solea senegalensis and Pomatochistus microps. Aquatic Toxicology, 102, 216-277.

Gallardo-Madueño, R.; Leal, J.F.; Dorado, G.; Holmgren, A.; López-Barea, J. \& Pueyo, C. (1998). In vivo transcription of $n r d A B$ operon and of grxA and fpg genes is triggered in Escherichia coli lacking both thioredoxin and glutaredoxin 1 or thioredoxin and glutathione, respectively. The Journal of Biological Chemistry, 273 (29), 18382-18388.

García-López, A.; Fernández-Pasquier, V.; Couto, E.; Canario, A.V.M.; Sarasquete, C. \& Martínez-Rodriguez, G. (2006a). Non-invasive assessment of reproductive status and cycle of sex steroid levels in a captive broodstock of Senegalese sole Solea senegalensis (Kaup). Aquaculture, 254, 583-593.

García-López, A.; Anguis, V.; Couto, E.; Canario, A.V.M.; Cañavate, J.P.; Sarasquete, C. \& Martínez-Rodriguez, G. (2006b). Testicular development and plasma sex steroid levels in cultured male Senegalese sole Solea senegalensis Kaup. General and Comparative Endocrinology, 147, 343-351.

García-López, A.; Couto, E.; Canario, A.V.M.; Sarasquete, C. \& Martínez-Rodriguez, G. (2007). Ovarian development and plasma sex steroid levels in cultured female Senegalese sole Solea senegalensis. Comparative Biochemistry and Physiology - Part A, 146, 342-354.

Gavaia, P.J.; Dinis, M.T. \& Cancela, M.L. (2002). Osteological development and abnormalities of the vertebral column and caudal skeleton in larval and juvenile stages of hatchery-reared Senegal sole (Solea senegalensis). Aquaculture, 211, 305-323.

Gavaia, P.J.; Simes, D.C.; Ortiz-Delgado, J.B.; Viegas, C.S.B.; Pinto, J.P.; Kelsh, R.N.; Sarasquete, C. \& Cancela, M.L. (2006). Osteocalcin and matrix Gla protein in zebrafish (Danio rerio) and Senegal sole (Solea senegalensis): Comparative gene and protein expression during larval development through adulthood. Gene Expression Patterns, 6, 637-652.

Geist, J.; Werner, I.; Eder, K.J. \& Leutenegger, C.M. (2007). Comparisons of tissue-specific transcription of stress response genes with whole animal endpoints of adverse effect in striped bass (Morone saxatilis) following treatment with copper and esfenvalerate. Aquatic Toxicology, 85(1), 28-39.

Gonzalez-Fernández, M.; García-Barrera, T.; Jurado, J.; Prieto-Álamo, M.J.; Pueyo, C.; LópezBarea, J. \& Gómez-Ariza, J.L. (2008). Integrated application of transcriptomics, proteomics, and metallomics in environmental studies. Pure and Applied Chemistry, 80, 2609-2626.

James, P. (1997). Protein identification in the post-genome era: the rapid rise of proteomics. Quarterly Review of Biophysics, 30, 279-331.

Jebali, J.; Banni, M.; Gerbej, H.; Boussetta, H.; López-Barea, J. \& Alhama, J. (2008). Metallothionein induction bu $\mathrm{Cu}, \mathrm{Cd}$ and $\mathrm{Hg}$ in Dicentrarchus labrax liver: assessment by RP-HPLC with fluorescent detection and spectrophotometry. Marine Environmental Research, 65, 358-363.

Jiménez, A.; Prieto-Álamo, M.J.; Fuentes-Almagro, C.A.; Jurado, J.; Gustafsson, J.A.; Pueyo, C. \& Miranda-Vizuete, A. (2005) Absolute mRNA levels and transcriptional regulation of the mouse testis-specific thioredoxins. Biochemical and Biophysical Research Communications, 330, 56-74. 
Jiménez-Tenorio, N.; Morales-Caselles, C.; Kalman, J.; Salamanca, M.J.; González de Canales, M.L.; Sarasquete, C. \& DelValls, T.A. (2007). Determining sediment quality for regulatory proposes using fish chronic assays. Environment International, 33, 474480.

Jiménez-Tenorio, N.; Salamanca, M.J.; García-Luque, E.; González de Canales, M.L. \& DelValls, T.A. (2008). Chronic bioassay in benthic fish for the assessment of the quality of sediments in different areas of the coast of Spain impacted by acute and chronic oilspills. Environmental Toxicology, 23, 634-642.

Jurado, J.; Prieto-Álamo, M.J.; Madrid-Risques, J. \& Pueyo, C. (2003) Absolute gene expression patterns of thioredoxn and glutaredoxin redox systems in mouse. The Journal of Biological Chemistry, 278 (46), 45546-45554.

Jurado, J.; Fuentes-Almagro, C.A.; Prieto-Álamo, M.J. \& Pueyo, C. (2007) Alternative splicing of $c$-fos pre-mRNA : contribution of the rates of synthesis and degradation to the copy number of each transcript isoform and detection of a truncated c-Fos immunoreactive species. BMC Molecular Biology, 8, 83.

Kültz, D.; Fiol, D.; Valkova, N.; Gomez-Jimenez, S.; Chan, S.Y.; \& Lee, J. (2007) Functional genomics and proteomics of the cellular stress response in «non-model» organisms. The Journal of Experimental Biology, 210, 1593-1601.

Lenartova, V.; Holovska, K.; Pedrajas, J.R.; Martínez-Lara, E.; Peinado, J.; López-Barea, J.; Rossival, I. \& Kosuth, P. (1997). Antioxidant and detoxifying fish enzymes as biomarkers of river pollution. Biomarkers, 2, 247-252.

López-Barea, J. (1995a). Biomarkers in Ecotoxicology: an Overview, In: Toxicology in Transition, Degen, G.H.; Seiler, J.P. \& Bentely, P. (Eds.), 57-79, Springer, ISBN 9783540587811, Berlin, Germany.

López-Barea, J. (1995b). Biomarcadores que detectan contaminantes ambientales. In: Actas del V Congreso Nacional de Acuicultura, Castelló, F. \& Calderer, A. (Eds.), 953-958, Publicaciones de la Universidad de Barcelona, Barcelona, Spain.

López-Barea, J. \& Pueyo, C. (1998). Mutagen content and metabolic activation of promutagens by molluscs as biomarkers of marine pollution. Mutation Research, 399, 3-15.

López-Barea, J. \& Gómez-Ariza, J.L. (2006). Environmental proteomics and metallomics. Proteomics, 6 (Suppl 1), S51-S62.

López-Galindo, C.; Vargas-Chacoff, L.; Nebot, E.; Casanueva, J.F.; Rubio, D.; Solé, M. \& Mancera, J.M. (2010a). Biomarker responses in Solea senegalensis exposed to sodium hypochlorite used as antifouling. Chemosphere, 78, 885-893.

López-Galindo, C.; Vargas-Chacoff, L.; Nebot, E.; Casanueva, J.F.; Rubio, D.; Solé, M. \& Mancera, J.M. (2010b). Sublethal effects or the organic antifoulant Mexel ${ }^{\circledR 4} 32$ on ormoregulation and xenobiotic detoxification in the flatfish Solea senegalensis. Chemosphere, 79, 78-85.

Manchado, M.; Michán, C. \& Pueyo, C. (2000). Hydrogen peroxide activates the SoxRS regulon in vivo. The Journal of Bacteriology, 182(23), 6842-6844.

Manchado, M.; Infante, C.; Asensio, E. \& Cañavate, J.P. (2007). Differential gene expression and dependence on thyroid hormones of two glyceraldehyde-3-phosphate dehydrogenases in the flatfish Senegalese sole (Solea senegalensis Kaup). Gene, 400(12), 1-8.

Martínez-Lara, E.; Pascual, P.; Toribio, F.; López-Barea, J. \& Bárcena, J.A. (1992). Rapid method for the quantification of glutathione transferase isoenzymes in crude extracts. Journal of Chromatography A, 609, 141-146. 
Martínez-Lara, E.; Toribio, F.; López-Barea, J. \& Bárcena, J.A. (1996). Glutathione-Stransferase isoenzyme patterns in the gilthead seabream (Sparus aurata) exposed to environmental contaminants. Comparative Biochemistry and Physiology - Part C: Toxicology \& Pharmacology, 113, 215-220.

Martínez-Lara, E.; George, S.G.; López-Barea, J. \& Bárcena, J. (1997). Purification and characterization of multiple glutathione transferase isoenzymes from grey mullet liver. Cellular and Molecular Life Sciences, 53, 759-768.

Mastellos, D.; Andronis, C.; Persidis, A. \& Lambris, J.D. (2005). Novel biological networks modulated by complement. Clinical Immunology, 115(3), 225-235.

Michan, C.; Manchado, M.; Dorado, G. \& Pueyo, C. (1999). In vivo transcription of the Escherichia coli oxyR regulon as a function of growth phase and in response to oxidative stress. The Journal of Bacteriology., 181(9), 2759-2764.

Michan, C.; Monje-Casas, F. \& Pueyo, C. (2005). Transcript copy number of genes for DNA repair and translesion synthesis in yeast: contribution of transcription rate and mRNA stability to the steady-state level of each mRNA along with growth in glucose-fermentative medium. DNA Repair, 4(4), 469-478.

Monje-Casas, F.; Jurado, J.; Prieto-Álamo, M.J.; Holmgren, A. \& Pueyo, C. (2001) Expression analysis of the nrdHIEF operon from Escherichia coli. Conditions that trigger the transcript level in vivo. Journal of Biological Chemistry, 276 (21), 18031-18037.

Monje-Casas, F.; Michan, C. \& Pueyo, C. (2004). Absolute transcript levels of thioredoxinand glutathione-dependent redox systems in Saccharomyces cerevisiae: response to stress and modulation with growth. Biochemical Journal, 383(Pt 1), 139-147.

Montes-Nieto, R.; Fuentes-Almagro, C.A.; Bonilla-Valverde, D.; Prieto-Álamo, M.J.; Jurado, J.; Carrascal, M.; Gómez-Ariza, J.L.; López-Barea, J. \& Pueyo, C. (2007). Proteomics in free-living Mus spretus to monitor terrestrial ecosystems. Proteomics, 7, 4376-4387.

Montes-Nieto, R.; García-Barrera, T.; Gómez-Ariza, J.L. \& López-Barea, J. (2010). Environmental monitoring of Domingo Rubio stream (Huelva Estuary, SW Spain) by combining conventional biomarkers and Proteomic analysis in Carcinus maenas. Environmental Pollution, 158, 401-408.

Morales-Caselles, C.; Jiménez-Tenorio, N.; González de Canales, M.L.; Sarasquete, C. \& DelValls, T.A. (2006). Ecotoxicity of sediments contaminated by the oil spill associated with the tanker "Prestige" using juveniles of the fish Sparus aurata. Archives of Environmental Contamination and Toxicology, 51, 652-660.

Morais, S.; Koven, W.; Rønnestad, I.; Dinis, M.T. \& Conceiçao, L.E.C (2005). Dietary protein/lipid ratio affects growth and amino acid and fatty acid absorption and metabolism in Senegalese sole (Solea senegalensis Kaup 1858) larvae. Aquaculture, 246, 347-357.

Morais, S.; Conceiçao, L.E.C.; Rønnestad, I.; Koven, W.; Cahu, C.; Zambonino Infante, J.L. \& Dinis, M.T. (2007). Dietary neutral lipid level and source in marine fish larvae: Effects on digestive physiology and food intake. Aquaculture, 268, 106-122.

Obayashi, T. \& Kinoshita, K. (2011). COEXPRESdb: a database to compare gene coexpression in seven model animals. Nucleic Acids Research, 39 (Suppl 1), D1016D1022.

Oliva, M.; González de Canales, M.L.; Gravato, C.; Guilhermino, L. \& Perales, J.A. (2010). Biochemical effects and polycyclic aromatic hydrocarbons (PAHs) in senegal sole (Solea senegalensis) from a Huelva estuary (SW Spain). Ecotoxicology and Environmental Safety, 73, 1842-1851.

Ortiz-Delgado, J.B.; Ruane, N.M.; Pousao-Ferreira, P.; Dinis, M.T. \& Sarasquete, C. (2006). Thyroid gland develoment in Senegalese sole (Solea senegalensis Kaup 1858) during 
early life stages: A histochemical and immunohistochemical approach. Aquaculture, 260, 346-356.

Osuna-Jiménez, I.; Williams, T.D.; Prieto-Álamo, M.-J.; Abril, N.; Chipman, J.K. \& Pueyo, C. (2009). Immune- and stress-related transcriptomic responses of Solea senegalensis stimulated with lipopolysaccharide and copper sulphate using heterologous cDNA microarrays. Fish \& Shellfish Immunology, 26, 699-706.

Pagan, J.K.; Wylie, F.G.; Joseph, S.; Widberg, C.; Bryant, N.J.; James, D.E. \& Stow, J.L. (2003). The t-SNARE syntaxin 4 is regulated during macrophage activation to function in membrane traffic and cytokine secretion. Current Biology, 13(2), 156-160.

Pascual, P.; Rodríguez-Ariza, A.; Navas, J.I.; Toribio, F. \& López-Barea, J. (1995a). Cambios bioquímicos estacionales durante el cultivo de doradas (Sparus aurata). In: Actas del $V$ Congreso Nacional de Acuicultura, Castelló, F. \& Calderer, A. (Eds.), 582-587, Publicaciones de la Universidad de Barcelona, Barcelona, Spain.

Pascual, P.; Navas, J.I.; Toribio, F. \& López-Barea, J. (1995b). Indicadores bioquímicos de esters en doradas (Sparus aurata). In: Actas del V Congreso Nacional de Acuicultura, Castelló, F. \& Calderer, A. (Eds.), 754-759, Publicaciones de la Universidad de Barcelona, Barcelona, Spain.

Pascual, P.; Navas, J.I.; Toribio, F. \& López-Barea, J. (1997). Cambios clínicos estacionales en la carga energética adenílica y guanílica de doradas (Sparus aurata). In: Actas del VI Congreso Nacional de Acuicultura, de Costa, J.; Abellán, E.; García, B.; Ortega, A. \& Zamora, S. (Eds.), 832-837, Publicaciones de la Universidad de Murcia, Murcia, Spain.

Pascual, P.; Pedrajas, J.R.; Toribio, F.; López-Barea, J. \& Peinado, J. (2003). Effect of food deprivation on oxidative stress biomarkers in fish (Sparus aurata). Chemico-Biological Interactions, 145, 191-199.

Pedrajas, J.R.; Peinado, J. \& López-Barea J. (1993). Purification of Cu,Zn-superoxide dismutase isoenzymes from fish liver: appearance of new isoforms as consequence of pollution. Free Radical Research Communications, 19, 29-41.

Pedrajas, J.R.; Peinado, J. \& López-Barea J. (1995). Oxidative stress in fish exposed to model xenobiotics. Oxidatively modified forms of $\mathrm{Cu}, \mathrm{Zn}$-superoxide dismutase as potential biomarkers. Chemico-Biological Interactions, 98, 267-282.

Pedrajas, J.R.; Gavilanes, F.; López-Barea, J. \& Peinado, J. (1998). Incubation of superoxide dismutase with malondialdehyde and 4-hydroxy-2-nonenal forms new active isoforms and adducts. An evaluation of xenobiotics in fish. Chemico-Biological Interactions, 116, 1-17.

Pinto, W.; Rodrigues, V.; Dinis, M.T. \& Aragão, C. (2010). Can dietary amino acid supplementation be beneficial during fish metamorphosis?. Aquaculture, 310, 200 205.

Prieto-Álamo, M.J.; Jurado, J.; Gallardo-Madueño, R.; Monje-Casas, F.; Holmgren, A. \& Pueyo, C. (2000). Transcriptional regulation of glutaredoxin and thioredoxin pathways and related enzymes in response to oxidative stress. The Journal of Biological Chemistry, 275(18), 13398-13405.

Prieto-Álamo, M.J.; Cabrera-Luque, J.M. \& Pueyo C. (2003). Absolute quantitation of normal and ROS-induced patterns of gene expression: an in vivo real-time PCR study in mice. Gene Expression, 11, 23-34.

Prieto-Álamo, M.J.; Abril, N.; Osuna-Jimenez, I. \& Pueyo, C. (2009). Solea senegalensis genes responding to lipopolysaccharide and copper sulphate challenges: Large-scale identification by suppression subtractive hybridization and absolute quantification of transcriptional profiles by real-time RT-PCR. Aquatic Toxicology, 91, 312-319. 
Pueyo, C.; Jurado, J.; Prieto-Álamo, M.J.; Monje-Casas, F. \& López-Barea, J. (2002). Multiplex reverse transcription-polymerase chain reaction for determining transcriptional regulation of thioredoxin and glutaredoxin pathways. Methods in Enzymology, 247, 441-451.

Pueyo, C.; Gómez-Ariza, J.L.; Bello-López, M.A.; Fernández-Torres, R.; Abril, N.; Alhama, J.; García-Barrera, T. \& López-Barea, J. (2011). New methodologies for assessing the presence and ecological effects of pesticides in Doñana National Park (SW Spain). In: Pesticides in the Modern World / Book 1, Bakic, S. (Ed.), 165-196, InTech Open Access Publisher, ISBN 978-953-307-437-5, Rijeka, Croatia.

Qureshi, N.; Perera, P.Y.; Shen, J.; Zhang, G.; Lenschat, A.; Splitter, G.; Morrison, D.C. \& Vogel, S.N. (2003). The proteasome as a lipopolysaccharide-binding protein in macrophages: differential effects of proteasome inhibition on lipopolysaccharideinduced signaling events. The Journal of Immunology, 171(3), 1515-1525.

Reynaud, S.; Raveton, M. \& Ravanel, P. (2008). Interactions between immune and biotransformation systems in fish: a review. Aquatic Toxicology, 87(3), 139-145.

Ribeiro, L.; Sarasquete, C. \& Dinis, M.T. (1999a). Histological and histochemical development of the digestive tract system of Solea senegalensis (Kaup, 1858) larvae. Aquaculture, 171, 293-308.

Ribeiro, L.; Zambonino-Infante, J.L.; Cahu, C. \& Dinis, M.T. (1999b). Development of digestive enzymes in larvae of Solea senegalensis, Kaup 1858. Aquaculture, 179, $293-$ 308.

Rodiles, A.; Herrera, M.; Hachero, I.; Rosano, M.; Ferrer, J.R.; Márquez, J.M. \& Navas, J.I. (2005). Influence of different bottom types on the Senegal sole Solea senegalensis Kaup, 1858 ongrowing. Boletín del Instituto Español de Oceanografía, 21, 195-199.

Rodríguez-Ariza, A.; Abril, N.; Navas, J.I.; Dorado, G.; López-Barea, J. \& Pueyo, C. (1992). Metal, mutagenicity and biochemical studies on bivalve molluscs from Spanish coasts. Environmental and Molecular Mutagenesis, 19, 112-124.

Rodríguez-Ariza, A.; Peinado, J.; Pueyo, C. \& López-Barea, J. (1993). Biochemical indicators of oxidative stress in fish from polluted littoral areas. Canadian Journal of Fisheries and Aquatic Sciences, 50, 2568-2573.

Rodríguez-Ariza, A.; Dorado, G.; Navas, J.I.; Pueyo, C. \& López-Barea, J. (1994a). Promutagen activation by fish liver as a biomarker of littoral pollution. Environmental and Molecular Mutagenesis, 24, 116-123.

Rodríguez-Ariza, A.; Toribio, F. \& López-Barea, J. (1994b). Rapid determination of glutathione status in fish liver using high-performance liquid chromatography and electrochemical detection. The Journal of Chromatography B, 656, 311-318.

Rodríguez-Ortega, M.J.; Alhama, J.; Funes, V.; Romero-Ruíz, A.; Rodríguez-Ariza, A. \& López-Barea, J. (2002). Biochemical biomarkers of pollution in the clam Chamaelea gallina from South-Spanish littoral. Environmental Toxicology \& Chemistry, 21, 542549.

Rodríguez-Ortega, M.J.; Grosvik, B.E.; Rodríguez-Ariza, A.; Goksoyr, A. \& López-Barea, J. (2003). Changes in protein expression profiles in bivalve molluscs (Chamaelea gallina) exposed to four environmental pollutants. Proteomics, 3, 1535-1543.

Romero-Ruíz, A.; Amezcua, O.; Rodríguez-Ortega, M.J.; Muñoz, J.L.; Alhama, J.; RodríguezAriza, A.; Gómez-Ariza, J.L. \& López-Barea, J. (2003). Oxidative stress biomarkers in the bivalve Scrobicularia plana transplanted to the Guadalquivir Estuary (S Spain) after Aznalcóllar mining spill. Environmental Toxicology \& Chemistry, 22, 92-100. 
Romero-Ruiz, A.; Carrascal, M.; Alhama, J.; Gómez-Ariza, J.L.; Abian, J. \& López-Barea, J. (2006). Environmental proteomic studies in clams from the Doñana bank of Guadalquivir Estuary (SW Spain). Proteomics, 6 (Suppl 1), S245-S255.

Romero-Ruiz, A.; Alhama, J.; Blasco, J.; Gómez-Ariza, J.L. \& López-Barea, J. (2008). New metallothionein assay in Scrobicularia plana: heating effect and correlation with other biomarkers. Environmental Pollution, 156, 1340-1347.

Rønnestad, I.; Conceiçao, L.E.C.; Aragão, C. \& Dinis, M.T. (2001). Assimilation and catabolism of dispensable and indispensable free amino acids in post-larval Senegal sole (Solea senegalensis). Comparative Biochemistry and Physiology - Part C: Toxicology $\mathcal{E}$ Pharmacology, 130, 461-466.

Rønnestad, I.; Tonheim, S.K.; Fyhn, H.J.; Rojas-García, C.R.; Kamisaka, Y.; Koven, W.; Finn, R.N.; Terjesen, B.F.; Barr, Y. \& Conceiçao, L.E.C. (2003). The supply of amino acids during early feeding stages of marine fish larvae: a review of recent findings. Aquaculture, 227, 147-164.

Rueda-Jasso, R.; Conceiçao, L.E.C.; Dias, J.; De Coen, W.; Gomes, E.; Rees, J.F.; Soares, F.; Dinis, M.T. \& Sorgeloos, P. (2004). Effect of dietary non-protein energy levels on condition and oxidative status of Senegalese sole (Solea senegalensis) juveniles. Aquaculture, 231, 417-433.

Ruiz-Laguna, J.; Abril, N.; Prieto-Álamo, M.J.; López-Barea, J. \& Pueyo, C. (2005). Tissue, species and enviromental differences in absolute quantities of murine mRNAs coding for $\alpha, \mu, \omega, \pi$ and $\theta$ glutathione S-transferases. Gene Expression, 12, 165-176.

Ruiz-Laguna, J.; Abril, N.; García-Barrera, T.; Gómez-Ariza, J.L.; López-Barea, J. \& Pueyo, C. (2006). Absolute transcript expression signatures of Cyp and Gst genes in Mus spretus to detect environmental contamination. Environmental Science E Technology, 40, 3646-3652.

Salas-Leiton, E.; Cánovas-Conesa, B.; Zerolo, R.; López-Barea, J.; Cañavate, J.P. \& Alhama, J. (2009). Proteomics of juvenile Senagal sole (Solea senegalensis) affected by gas bubble disease in hyperoxygenated ponds. Marine Biotechnology, 11, 473-487.

Simpson, R.J. (2003). Proteins and Proteomics. A Laboratory Manual. Cold Spring Harbor, USA: Cold Spring Harbor Laboratory Press.

Solé, M.; Lima, D.; Reis-Henriques, M.A. \& Santos, M.M. (2008). Stress biomarkers in juvenile Sole, Solea senegalensis, exposed to water-accommodated fraction of the «Prestige» fuel oil. Bulletin of Environmental Contamination and Toxicology, 80, 19-23.

Sukardi, H.; Ung, C.Y.; Gong, Z. \& Lam, S.H. (2010). Incorporating zebrafish Omics into Chemical Biology and Toxicology. Zebrafish, 7, 41-52.

Swain, P.; Nayak S.K.; Nanda P.K. \& Dash S. (2008). Biological effects of bacterial lipopolysaccharide (endotoxin) in fish: A review. Fish \& Shellfish Immunology, 25(3), 191-201.

Thorgaard, G.H.; Bailey, G.S.; Williams, D.; Buhler, D.R.; Kaattari, S.L.; Ristow, S.S.; Hansen, J.D.; Winton, J.R.; Bartholomew, J.L.; Nagler, J.J.; Walsh, P.J.; Vijayan, M.M.; Devlin, R.H.; Hardy, R.W.; Overturf, K.E.; Young, W.P.; Robison, B.D.; Rexroad, C. \& Palti, Y. (2002). Status and opportunities for genomics research with rainbow trout. Comparative Biochemistry and Physiology, 133(4), 609-646.

Valente, L.M.P.; Linares, F.; Villanueva, J.L.R.; Silva, J.M.G.; Espe, M.; Escórcio, C.; Pires, M.A.; Saavedra, M.J.; Borges, P.; Medale, F.; Alvarez-Blázquez, B. \& Peleteiro, J.B. (2011). Dietary protein source or energy levels have no major impact on growth performance, nutrient utilisation or flesh fatty acids composition of market-sized Senegalese sole. Aquaculture, 318, 128-137. 
Van Aggelen, G.V.; Ankley, G.T.; Baldwin, W.S.; Bearden, D.W.; Benso, W.H.; Chipman, J.K.; Collette, T.W.; Craft, J.A.; Denslow, N.D.; Embry, M.R.; Falciani, F.; George, S.G.; Helbing, C.C.; Hoekstra, P.F.; Iguchi, T.; Kagami, Y.; Katsiadaki, I.; Kille, P.; Liu, L.; Lord, P.G.; McIntyre, T.; O’Neill, A.; Osachoff, H.; Perkins, E.J.; Santos, E.M.; Skirrow, R.C.; Snape, J.R.; Tyler, C.R.; Versteeg, D.; Viant, M.R.; Volz, D.C.; Williams, T.D. \& Yu, L. (2010). Integrating Omic technologies into aquatic Ecological Risk Assessment and Environmental Monitoring: hurdles, achievements, and future outlook. Environmental Health Perspectives, 118, 1-5.

Viant, M.R. (2007). Metabolomics of aquatic organisms: the new «omics» on the block. Marine Ecology Progress Series, 332, 301-306.

Vioque-Fernández, A.; Alves-de-Almeida, E.; Ballesteros, J.; García-Barrera, T.; GómezAriza, J.L. \& López-Barea, J. (2007a). Doñana National Park survey using Procambarus clarkii as bioindicator: esterase inhibition and pollutant levels. Toxicology Letters, 168, 260-268.

Vioque-Fernández, A.; Alves-de-Almeida, E. \& López-Barea, J. (2007b). Esterases as pesticide biomarkers in crayfish (Procambarus clarkii, Crustacea): Tissue distribution, sensitivity to model compounds and recovery from inactivation. Comparative Biochemistry and Physiology - Part C: Toxicology \& Pharmacology, 145, 404-412.

Vioque-Fernández, A.; Alves-de-Almeida, E. \& López-Barea, J. (2009a). Assessment of Doñana National Park contamination in Procambarus clarkii: integration of conventional biomarkers and proteomic approaches. Science of the Total Environment, 407, 1784-1797.

Vioque-Fernández, A.; Alves-de-Almeida, E. \& López-Barea, J. (2009b). Biomarker responses and protein expression profile changes in Procambarus clarkii after chlorpyrifos or carbaryl exposure. Biomarkers, 14, 299-310.

Washburn, M.P.; Wolters, D. \& Yates, J.R. (2001). Large-scale analysis of the yeast proteome by multidimensional protein identification technology. Nature Biotechnology, 19 (3), 242-247.

Whyte, S.K. (2007). The innate immune response of finfish--a review of current knowledge. Fish E Shellfish Immunology, 23(6), 1127-1151.

Wilkins, M.R.; Pasquali, C.; Appel, R.D.; Ou, K.; Golaz, O.; Sanchez, J.-C.; Yan, J.X.; Gooley, A.A.; Hughes, G.; Humphery-Smith, I.; Williams, K.L. \& Hochstrasser, D.F. (1996). From proteins to proteomes: large scale protein identification by two-dimensional electrophoresis and amino acid analysis. Nature Biotechnology, 14, 61-65.

Williams, T.D.; Gensberg, K.; Minchin, S.D. \& Chipman, J.K. (2003). A DNA expression array to detect toxic stress response in European flounder (Platichthys flesus). Aquatic Toxicology, 65, 141-157.

Williams, T.D.; Diab, A.M.; George, S.G.; Godfrey, R.E.; Sabine, V.; Conesa, A.; Minchin, S.D.; Watts, P.C. \& Chipman, J.K. (2006). Development of the GENIPOL European Flounder (Platichthys flesus) microarray and determination of temporal transcriptional responses to cadmium at low dose. Environmental Science $\mathcal{E}$ Technology, 40, 6479-6488.

Williams, T.D.; Diab, A.M.; George, S.G.; Sabine, V. \& Chipman, J.K. (2007). Gene expression responses of European flounder (Platichthys flesus) to 17-beta estradiol. Toxicology Letters, 168(3), 236-248.

Williams, T.D.; Diab, A.; Ortega, F.; Sabine, V.S.; Godfrey, R.E.; Falciani., F.; Chipman, J.K. \& George, S.G. (2008). Transcriptomic responses of European flounder (Platichthys flesus) to model toxicants. Aquatic Toxicology, 90(2), 83-91. 


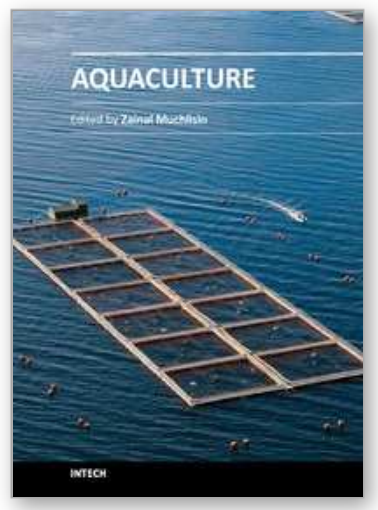

\author{
Aquaculture \\ Edited by Dr. Zainal Muchlisin
}

ISBN 978-953-307-974-5

Hard cover, 390 pages

Publisher InTech

Published online 27, January, 2012

Published in print edition January, 2012

This book provides an understanding on a large variety of aquaculture related topics. The book is organized in four sections. The first section discusses fish nutrition second section is considers the application of genetic in aquaculture; section three takes a look at current techniques for controlling lipid oxidation and melanosis in Aquaculture products. The last section is focused on culture techniques and management, ,which is the larger part of the book. The book chapters are written by leading experts in their respective areas. Therefore, I am quite confident that this book will be equally useful for students and professionals in aquaculture and biotechnology.

\title{
How to reference
}

In order to correctly reference this scholarly work, feel free to copy and paste the following:

María-José Prieto-Álamo, Inmaculada Osuna-Jiménez, Nieves Abril, José Alhama, Carmen Pueyo and Juan López-Barea (2012). Omics Methodologies: New Tools in Aquaculture Studies, Aquaculture, Dr. Zainal Muchlisin (Ed.), ISBN: 978-953-307-974-5, InTech, Available from:

http://www.intechopen.com/books/aquaculture/omics-methodologies-new-tools-in-aquaculture-studies

\section{INTECH}

open science | open minds

\section{InTech Europe}

University Campus STeP Ri

Slavka Krautzeka 83/A

51000 Rijeka, Croatia

Phone: +385 (51) 770447

Fax: +385 (51) 686166

www.intechopen.com

\section{InTech China}

Unit 405, Office Block, Hotel Equatorial Shanghai

No.65, Yan An Road (West), Shanghai, 200040, China

中国上海市延安西路65号上海国际贵都大饭店办公楼405单元

Phone: +86-21-62489820

Fax: +86-21-62489821 
(C) 2012 The Author(s). Licensee IntechOpen. This is an open access article distributed under the terms of the Creative Commons Attribution 3.0 License, which permits unrestricted use, distribution, and reproduction in any medium, provided the original work is properly cited. 